\title{
How to Turn Yeast Cells into a Sustainable and Switchable Biocatalyst? On-Demand Catalysis of Ketone Bioreduction or Acyloin Condensation
}

László Nagy-Győr, ${ }^{\dagger}$ Mihai Lăcătuș, ${ }^{\dagger}$ Diána Balogh-Weiser,${ }^{\dagger} \S$ Pál Csuka, ${ }^{\dagger}$ Viktória Bódai, \#,** Balázs Erdélyi, ${ }^{\#}$ Zsófia Molnár, ${ }^{\dagger}$ Gábor Hornyánszky, ${ }^{\dagger} \S$ Csaba Paizs, ${ }^{*}$ and László

$$
\text { Poppe } * \dagger, \ddagger, \S
$$

$\dagger$ Department of Organic Chemistry and Technology, Budapest University of Technology and Economics, Müegyetem Str., No. 3, H-1111 Budapest, Hungary

$\$$ Biocatalysis and Biotransformation Research Centre, Faculty of Chemistry and Chemical Engineering, Babeș-Bolyai University of Cluj-Napoca, Arany János Str., No. 11, RO-400028 Cluj-Napoca, Romania

§SynBiocat Ltd, Szilasliget Str., No. 3, H-1172 Budapest Hungary

\#Fermentia Microbiological Ltd, Berlini Str., No. 47-49, H-1045 Budapest, Hungary

** Witaria Ltd, Luther Str., No. 4-6, H-1087 Budapest, Hungary

25 Pages

28 Figures

9 Tables 


\section{Table of contents}

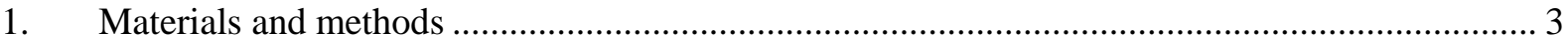

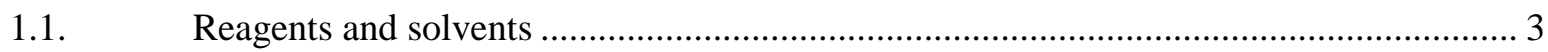

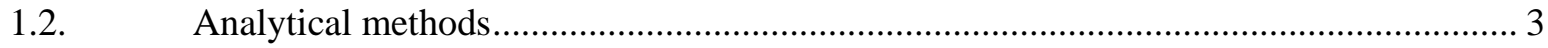

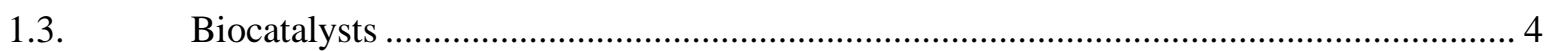

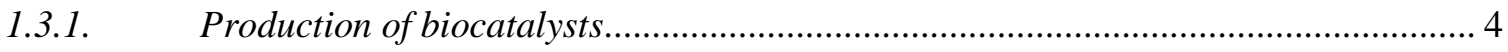

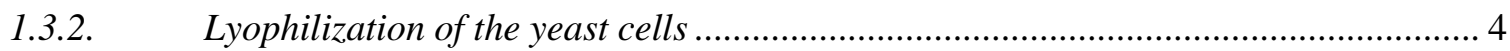

1.3.3. Immobilization of the yeast whole-cells in templated sol-gel matrices ......................... 4

1.3.4. Immobilization efficiency analysis by cell number counting ...................................... 4

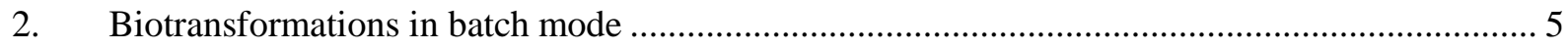

2.1. Comparison of lyophilized yeast cells in bioreduction of ketones 1a-d in presence of 2-

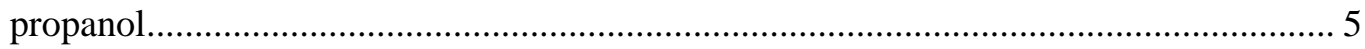

2.2. Bioreduction of ketones $\mathbf{1 a}$ and $\mathbf{1 b}$ with lyophilized cells in presence of various amounts

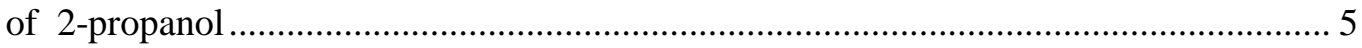

2.3. Bioreduction of ketones $\mathbf{1 a}$ and $\mathbf{1 b}$ with fresh harvested yeast cells.............................. 7

2.4. Bioreduction of ketones $\mathbf{1 a}$ and $\mathbf{1 b}$ with immobilized yeast cell biocatalysts................. 7

2.5. Bioreductions of prochiral ketones $\mathbf{1 a}$ and $\mathbf{1 b}$ with different forms of whole yeast cells 8

2.6. Storage stability of different forms of whole yeast cells ............................................. 8

2.7. Acyloin condensation mediated with freshly harvested cell paste or lyophilized whole

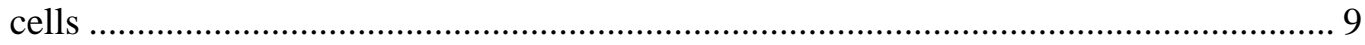

2.8. Acyloin condensation mediated by immobilized yeast cells........................................ 9

2.9. Switching between two types of batch mode biotransformations .................................. 9

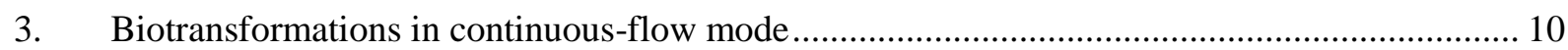

3.1. Enantiotope selective reduction of ketone 1a-d with immobilized yeast cell biocatalysts in continuous-flow mode at analytical scale

3.2. Enantiotope selective reduction of ketone 1a-d with immobilized yeast cell biocatalysts in continuous-flow mode at preparative scale ........................................................... 11

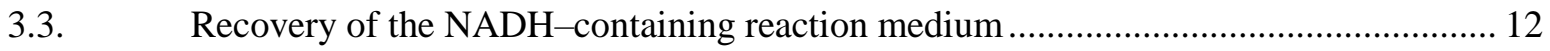

3.4. Acyloin condensation of benzaldehyde $\mathbf{3}$ using immobilized yeast cells at analytical

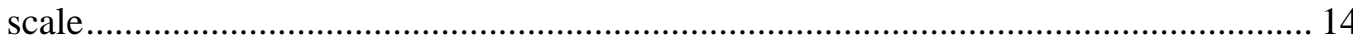

3.5. Acyloin condensation of benzaldehyde $\mathbf{3}$ using immobilized yeast cells at preparative

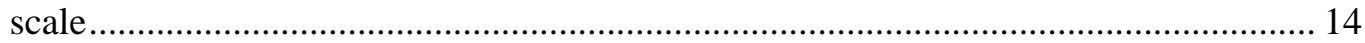

3.6. On demand switchable biotransformations under continuous-flow conditions .............. 15

4. NMR spectra of products and GC analysis of biotransformation products on chiral phase ....... 16 


\section{Materials and methods}

\subsection{Reagents and solvents}

Except otherwise not stated, all chemicals and starting materials were purchased from Sigma-Aldrich (St. Louis, MO, USA), Fluka (Milwaukee, WI, USA) or Alfa Aesar Europe (Karlsruhe, Germany). MAT540 (MATSPHERETM SERIES 540 - hollow silica microspheres etched with aminoalkyl and vinyl functions) was purchased from Materium Innovations (Granby, Canada).

\subsection{Analytical methods}

The ${ }^{1} \mathrm{H}-\mathrm{NMR}$ and ${ }^{13} \mathrm{C}-\mathrm{NMR}$ spectra of compounds 1a-d, 2a-d, 3 and $\mathbf{4}$ were recorded in $\mathrm{CDCl}_{3}$ at 25 ${ }^{\circ} \mathrm{C}$ on DRX-300 or Avance 400 spectrometers, Brucker BioSpin (Rheinstetten, Germany) operating at 300 or $400 \mathrm{MHz}$ and 75 or $101 \mathrm{MHz}$, respectively using the signal of the residual non-deuterated solvent as internal reference. NMR signals are given in ppm on the $\delta$ scale. Infrared spectra were recorded on an ALPHA FT-IR spectrometer, Bruker Optik (Ettlingen, Germany) and wavenumbers of bands are listed in $\mathrm{cm}^{-1}$. Elemental Analysis (CNH analysis) was performed using a vario MICRO cube CNHS elemental analyzer, Elementar (Langenselbold, Germany). The surface morphology of the samples was investigated with a JSM-5500LV scanning electron microscope (SEM) by JEOL (Akashima, Japan).

Substrate and products (1a-d, 2a-d; 3, 4, 5, 6 and 7) obtained in the biotransformations were analyzed by a 4890 GC equipment, Agilent (Santa Clara, CA, USA) with FID detector and Hydrodex $\beta$-6TBDM column $[25 \mathrm{~m} \times 0.25 \mathrm{~mm} \times 0.25 \mu \mathrm{m}$ film with heptakis-(2,3-di- $O$-methyl-6- $O$ - $t$-butyldimethylsilyl)- $\beta$ cyclodextrine; Macherey \& Nagel (Düren, Germany)] using $\mathrm{H}_{2}$ carrier gas (injector: $250{ }^{\circ} \mathrm{C}$, detector: $250{ }^{\circ} \mathrm{C}$, head pressure: 12 psi, split ratio: $\left.50: 1\right)$.

Table S1. GC temperature programs and response factors used for the conversion value and enantiomer composition determinations of the bioreduction samples of $\mathbf{1 a , b}$

\begin{tabular}{|c|c|c|c|c|c|}
\hline \multirow[t]{2}{*}{ Substrate } & \multirow[t]{2}{*}{ Temperature program } & \multicolumn{3}{|c|}{ Retention times (min) } & \multirow{2}{*}{$\begin{array}{c}\text { Response factors } \\
\qquad 1 \mathrm{a}: 2\end{array}$} \\
\hline & & 1 & $(S)-2$ & $(R)-2$ & \\
\hline $1 \mathbf{a}$ & $\begin{array}{c}5 \text { min at } 80^{\circ} \mathrm{C}, 80-120^{\circ} \mathrm{C}, \\
2^{\circ}{ }^{\circ} \mathrm{min}^{-1}\end{array}$ & 15.7 & 20.2 & 20.7 & 1.0 \\
\hline $1 \mathbf{b}$ & $50 \mathrm{~min}$ at $40^{\circ} \mathrm{C}$ & 14.9 & 39.5 & 39.7 & 1.0 \\
\hline 1c & $8 \mathrm{~min}$ at $120^{\circ} \mathrm{C}$ & 3.7 & 7 & 6.6 & 1.0 \\
\hline 1d & $20 \mathrm{~min}$ at $110^{\circ} \mathrm{C}$ & 10.1 & 14.6 & 15.4 & 1.0 \\
\hline
\end{tabular}

Table S2. GC temperature programs and response factors used for the conversion value and enantiomer composition determinations of the acyloin-condensation samples of $\mathbf{3}$

\begin{tabular}{|c|c|c|c|c|c|c|c|c|}
\hline \multirow[t]{2}{*}{ Substrate } & \multirow[t]{2}{*}{ Temperature program } & \multicolumn{6}{|c|}{ Retention times (min) } & \multirow{2}{*}{$\begin{array}{l}\text { Response } \\
\text { factors } \\
3: 4: 5\end{array}$} \\
\hline & & 3 & $(R)-4$ & $(S)-4$ & 5 & 6 & 7 & \\
\hline 3 & $\begin{array}{l}15 \min \text { at } 120^{\circ} \mathrm{C}, 120-150^{\circ} \mathrm{C} \text {, } \\
5^{\circ} \mathrm{C} \min ^{-1}, 10 \mathrm{~min} \text { at } 150{ }^{\circ} \mathrm{C}\end{array}$ & 3.0 & 8.9 & 9.6 & 5.1 & 4.2 & 19.3 & $1.1: 0.85: 1$ \\
\hline
\end{tabular}




\subsection{Biocatalysts}

\subsubsection{Production of biocatalysts}

Strains were stored in lyophilized ampules in strain culture collection of Witaria (Budapest, Hungary; for details on strains, see Figure S3). Yeasts are maintained and cultivated on Yeast Malt Agar (HiMedia M424) and Yeast Malt Broth (HiMedia M425). Cultivation was carried out as described earlier ${ }^{1}$ in 10 L fermenter.

\subsubsection{Lyophilization of the yeast cells}

Following cultivation, the cell lyophilization was carried out as described earlier. ${ }^{2}$

\subsubsection{Immobilization of the yeast whole-cells in templated sol-gel matrices}

The immobilization process is described in the Experimental Section of the main article.
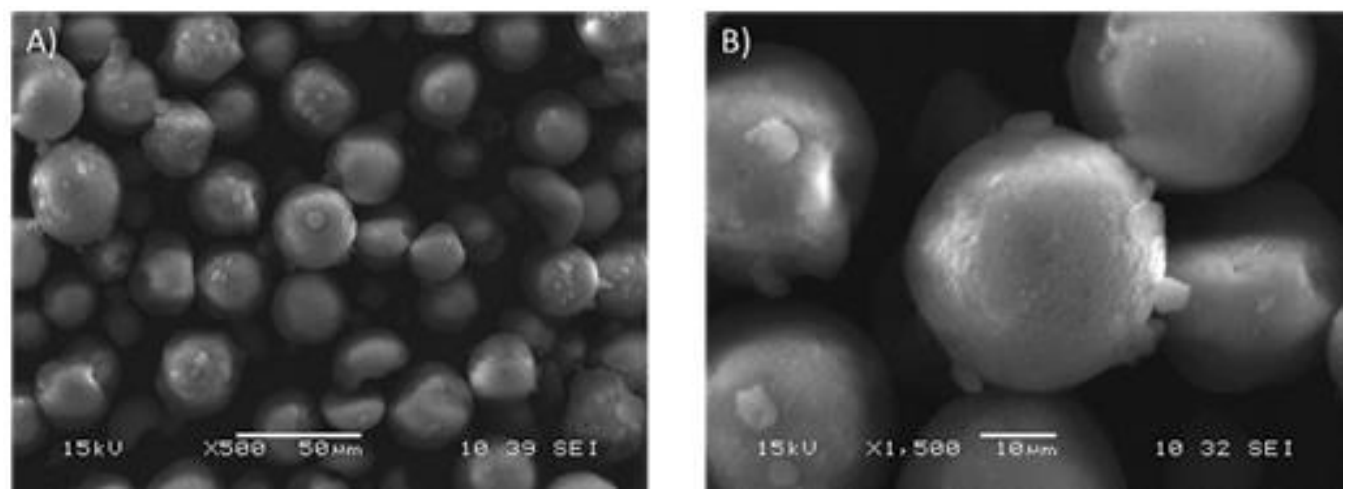

Figure S1. SEM images of MAT540, magnifications: A) 500x B) 1500x
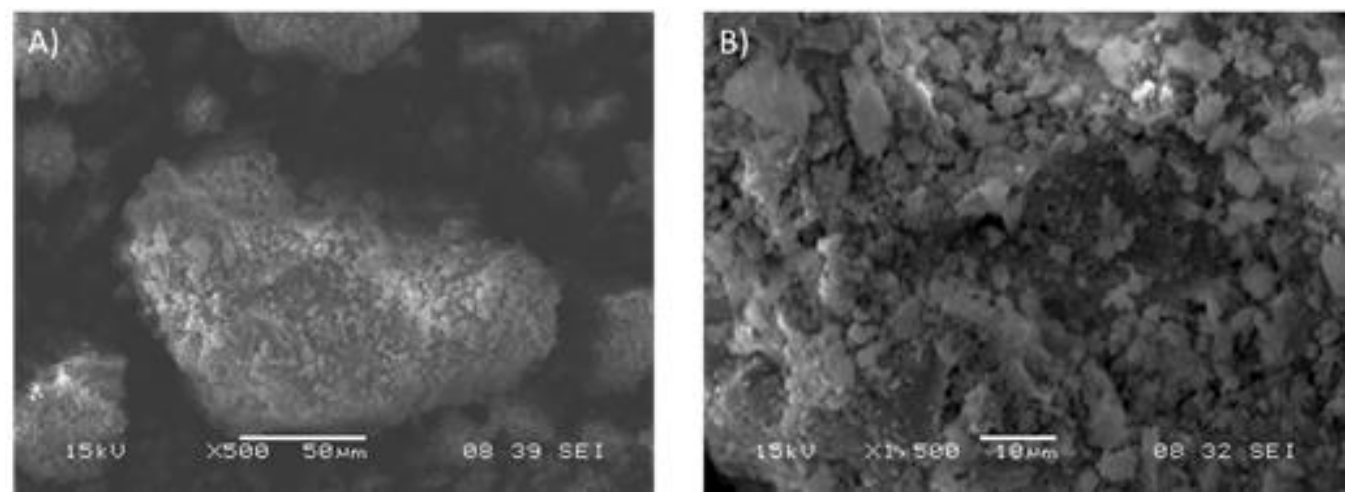

Figure S2. SEM images of the immobilized Lodderomyces elongisporus preparation, magnifications: A) 500x B) 1500x

\subsubsection{Immobilization efficiency analysis by cell number counting}

The immobilization yield was determined out as described earlier. ${ }^{3}$ The number of whole-cells prior to and after immobilization were determined in two ways: (i) the number of viable cells by dilution plating and viable plate counts and (ii) the total number of cells by Helber counting chamber. More than 99\% cell immobilization yield was achieved for each strain immobilization.

(i): Dilution plating was performed on agar plates containing the fermentation media for yeast cells 
(ii): Helber counting chamber (MOM Helber, Budapest, Hungary); chamber parameters: $0.01 \mathrm{~mm}$, $1 / 400 \mathrm{~mm}^{2}, 1 / 25 \mathrm{~mm}^{2}$.

\section{Biotransformations in batch mode}

\subsection{Comparison of lyophilized yeast cells in bioreduction of ketones 1a-d in presence of 2- propanol}

Lyophilized cells (300 mg) as biocatalyst were added to a mixture one of the ketones 1a-d (30 mM), 2propanol (4\% v/v) in phosphate buffer $(5 \mathrm{~mL}, 100 \mathrm{mM}, \mathrm{pH} 7.5)$ in $20 \mathrm{ml}$ Erlenmeyer-flasks. The mixtures were shaken on an orbital shaker $(750 \mathrm{rpm})$ at $30{ }^{\circ} \mathrm{C}$ for $24 \mathrm{~h}$. Then $0.5 \mathrm{ml}$ from the mixture was extracted with ethyl acetate $(1 \mathrm{~mL})$ dried over $\mathrm{Na}_{2} \mathrm{SO}_{4}$ and analyzed by GC. The conversion and enantiomeric excess were determined by GC as described in Section 1.2.

Table S3. Comparison of lyophilized yeast cells in the bioreduction of 1a-d in presence of 2-propanol (4v/v\%)

\begin{tabular}{lccccccccc}
\hline \multicolumn{1}{c}{ Strain name } & $c_{\mathbf{1 a}}(\%)$ & $e e_{(\mathrm{S})-\mathbf{2 a}}(\%)$ & $c_{\mathbf{1 b}}(\%)$ & $e e_{(\mathrm{S})-\mathbf{2 b}}(\%)$ & $c_{\mathbf{1 c}}(\%)$ & $e e_{(\mathrm{S})-\mathbf{2 c}}(\%)$ & $c_{\mathbf{1 d}}(\%)$ & $e e_{(\mathrm{S})-\mathbf{2 d}}(\%)$ \\
\hline W. subpelliculosus $($ WY13) & $56 \pm 0.5$ & $>99$ & $19 \pm 0.4$ & $>99$ & $5 \pm 0.4$ & $97 \pm 0.5$ & $17 \pm 0.7$ & $>99$ \\
W. subpelliculosus $(W Y 3)$ & $40 \pm 0.2$ & $70 \pm 1.6$ & $13 \pm 0.2$ & $>99$ & $6 \pm 0.7$ & $98 \pm 0.7$ & $18 \pm 1.0$ & $>99$ \\
Candida guillermondii (WY7) & $6 \pm 0.1$ & $78 \pm 0.8$ & $32 \pm 0.2$ & $87 \pm 0.7$ & $4 \pm 0.1$ & $13 \pm 0.2$ & $3 \pm 0.2$ & $49 \pm 1.0$ \\
Cryptococcus curvatus (WY5) & $3 \pm 0.1$ & a) & $11 \pm 0.2$ & $31 \pm 1$ & $13 \pm 0.4$ & $14 \pm 0.3$ & $4 \pm 1.0$ & $65 \pm 0.8$ \\
Debaryomyces hansenii (WY6) & $1 \pm 0.1$ & a) & a) & a) & a) & a) & a) & a) \\
\hline
\end{tabular}

a) No measurable activity was observed.

\subsection{Bioreduction of ketones $1 \mathrm{a}$ and $1 \mathrm{~b}$ with lyophilized cells in presence of various amounts of 2-propanol}

Lyophilized cells (300 mg) of various yeasts (Pichia carsonii, Lodderomyces elongisporus, Candida norvegica or Debaryomyces fabryi) were suspended in phosphate buffer $(5 \mathrm{~mL}, 100 \mathrm{mM}, \mathrm{pH} 7.5)$ containing one of the ketones 1a, and 1b, (30 mM) 2-propanol (2, 4, 8, 16, 20, 40, 60, 80 or $100 \mathrm{v} / \mathrm{v} \%)$ in $20 \mathrm{ml}$ Erlenmeyer-flasks. The mixture was shaken on an orbital shaker $(750 \mathrm{rpm})$ at $30^{\circ} \mathrm{C}$ for $24 \mathrm{~h}$. Then $0.5 \mathrm{ml}$ from the mixture was extracted with ethyl acetate $(1 \mathrm{~mL})$ dried over $\mathrm{Na}_{2} \mathrm{SO}_{4}$ and analyzed by GC. The conversion and enantiomeric excess were determined by GC as described in Section 1.2. 
A

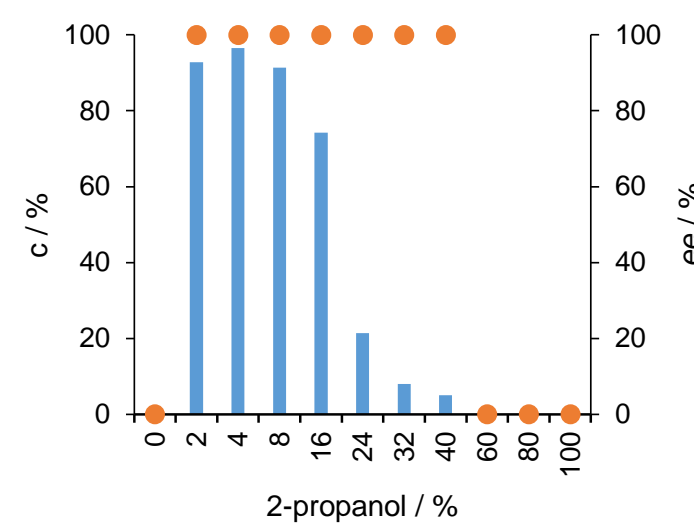

C

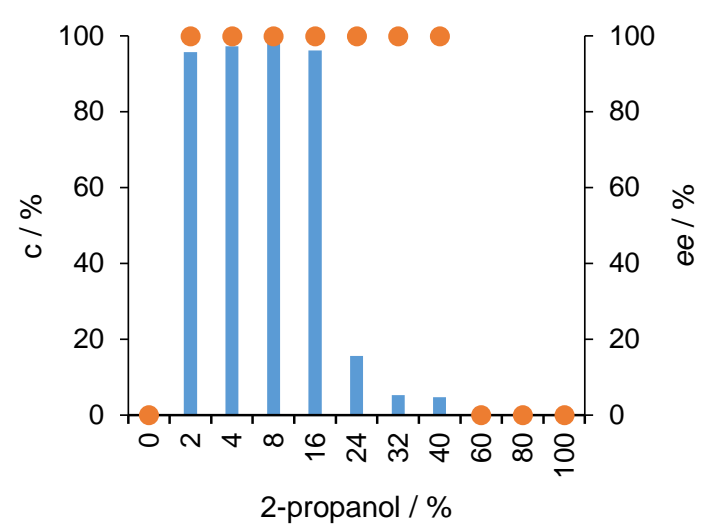

B

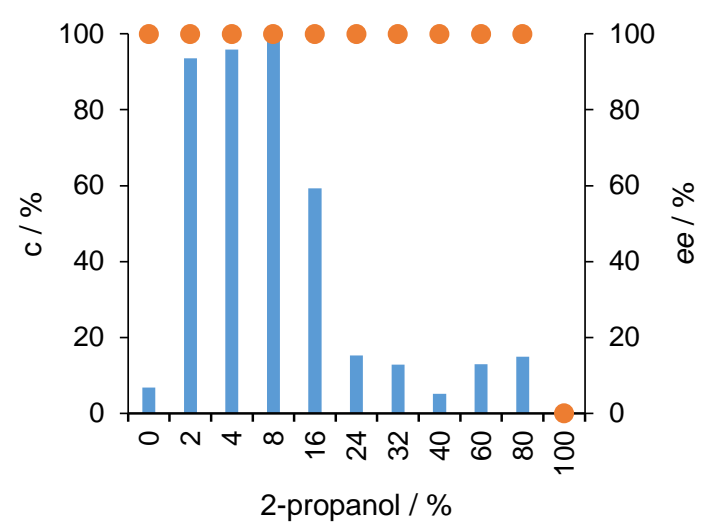

D

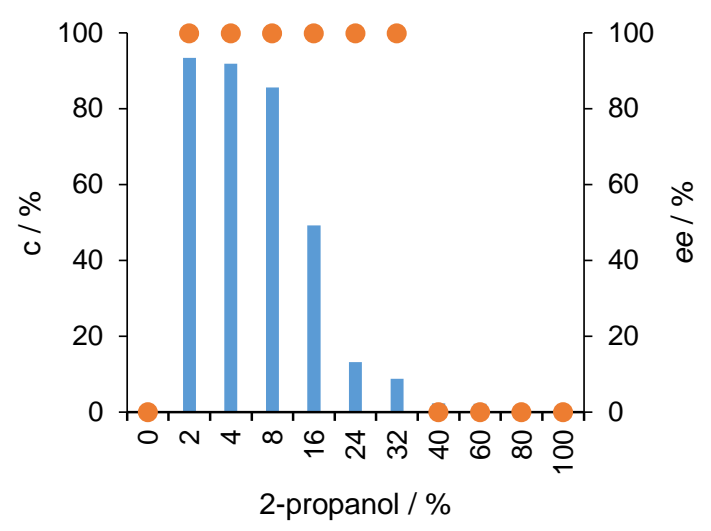

Figure S3. Effect of 2-propanol amount on bioreduction of ketone 1a mediated by A) P. carsonii; B) L. elongisporus; C) C. norvegica; D) D. fabryi. Conversion of the substrate 1a and enantiomeric excess of the product $(S)$-2a are shown for each reactions $\left(\square c_{1 \mathbf{a}} ; \bullet e e_{(S)-2 \mathrm{a}}\right)$ 
A

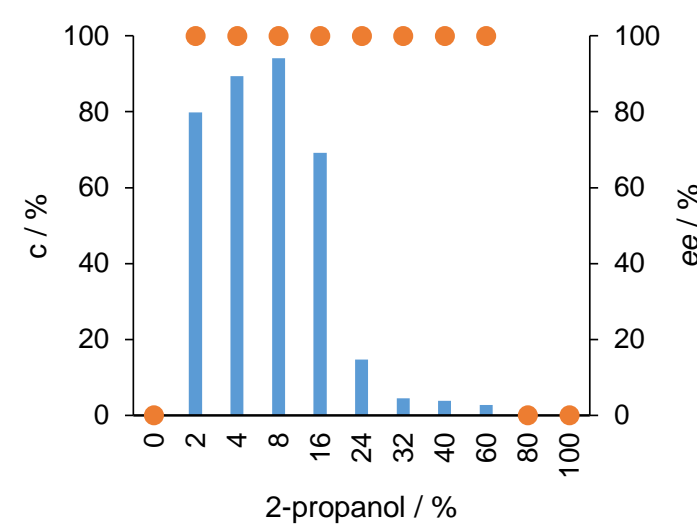

C

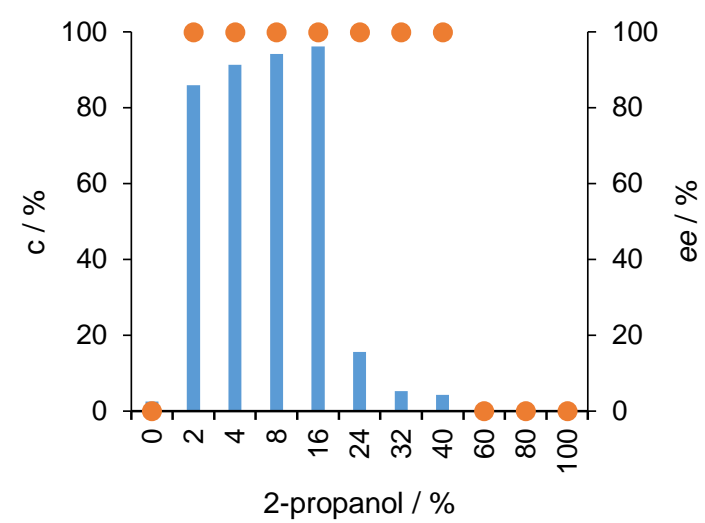

B

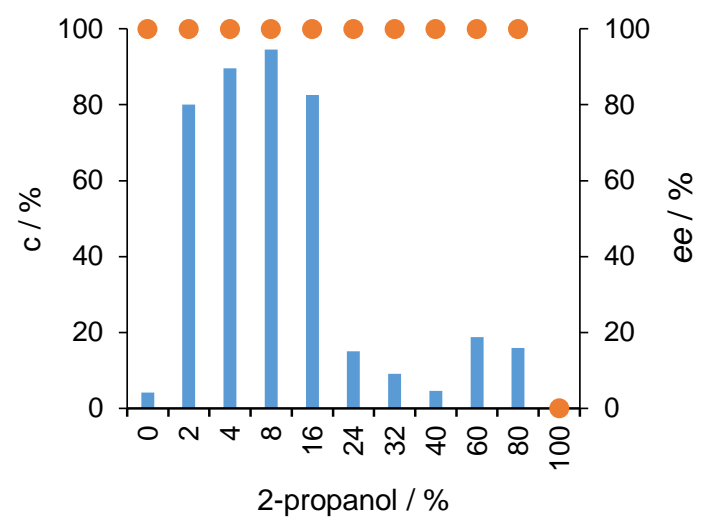

D

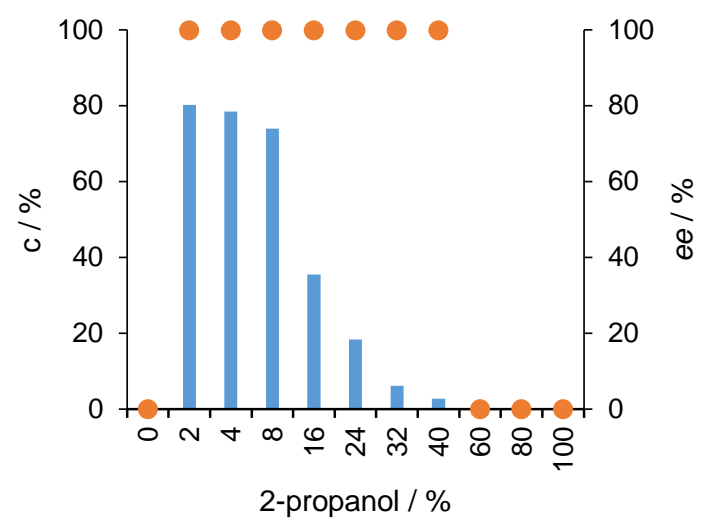

Figure S4. Effect of 2-propanol amount on bioreduction of ketone $\mathbf{1 b}$ mediated by A) P. carsonii; B) L. elongisporus; C) C. norvegica; D) D. fabryi. Conversion of the substrate $\mathbf{1 b}$ and enantiomeric excess of the product $(S)-\mathbf{2 b}$ are shown for each reactions $\left(\square c_{\mathbf{1 b}} ; \bullet e e_{(S)-2 \mathbf{b})}\right.$

\subsection{Bioreduction of ketones 1a-d with fresh harvested yeast cells}

Freshly harvested cell paste (100 mg) as biocatalyst was added to a mixture of ketones (1a-d, $15 \mathrm{mM})$, 2-propanol (2\% v/v) in phosphate buffer $(5 \mathrm{~mL}, 100 \mathrm{mM}, \mathrm{pH} 7.5)$ in $20 \mathrm{ml}$ Erlenmeyer-flasks. The mixtures were shaken on an orbital shaker $(750 \mathrm{rpm})$ at $30^{\circ} \mathrm{C}$ for $24 \mathrm{~h}$. Then $0.5 \mathrm{ml}$ from the mixture was extracted with ethyl acetate $(1 \mathrm{~mL})$ dried over $\mathrm{Na}_{2} \mathrm{SO}_{4}$ and analyzed by GC. The conversion and enantiomeric excess were determined by GC as described in Section 1.2.

\subsection{Bioreduction of ketones 1a-d with immobilized yeast cell biocatalysts}

Immobilized yeast cell biocatalyst (50 mg) was suspended in phosphate buffer $(2 \mathrm{~mL}, 100 \mathrm{mM}, \mathrm{pH} 7.5)$ containing the ketone (1a-d, $15 \mathrm{mM})$ and 2-propanol (2v/v\%) in $5 \mathrm{~mL}$ vials. The mixture was shaken on an orbital shaker $(750 \mathrm{rpm})$ at $30{ }^{\circ} \mathrm{C}$ for $24 \mathrm{~h}$. The samples from the reaction mixture $(100 \mu \mathrm{L}$, taken after $24 \mathrm{~h})$ were extracted with ethyl acetate $(600 \mu \mathrm{L})$. dried over $\mathrm{Na}_{2} \mathrm{SO}_{4}$ and analyzed by GC. The conversion and enantiomeric excess were determined by GC as described in Section 1.2 . 


\subsection{Bioreductions of prochiral ketones 1-d with different forms of whole yeast cells}

Biotransformation of ketones (1a-d, $15 \mathrm{mM})$ mediated by various forms of yeast cells biocatalyst (immobilized, $50 \mathrm{mg}$; fresh harvested paste, $100 \mathrm{mg}$; lyophilized, $100 \mathrm{mg}$ ) in phosphate buffer (100 $\mathrm{mM}, \mathrm{pH} 7.5)$ containing the and 2-propanol (2v/v\%) were performed as described in Sections 2.2, 2.3 and 2.4 of this document.

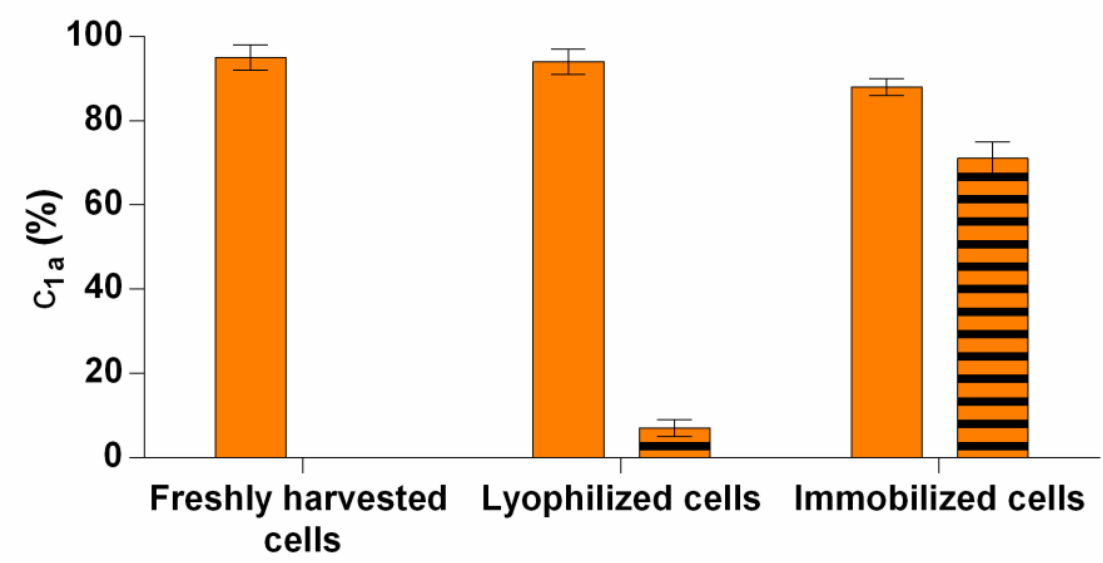

Figure S5. Recyclability of different forms of Lodderomyces elongisporus whole cells in bioreduction of 1a ( conversion c1a is represented: data of first run as color-filled bars; data of second run of biotransformation as color-filled black striped bars).

\subsection{Storage stability of different forms of whole yeast cells}

Storage stability of whole-cells (immobilized, $50 \mathrm{mg}$; fresh harvested paste, $100 \mathrm{mg}$; lyophilized, $100 \mathrm{mg}$ ) was tested by assaying the bioreduction of $1 \mathrm{a}$ at $30^{\circ} \mathrm{C}$ for $24 \mathrm{~h}$ with the actual form of cells. The experiments were performed as described previously in Sections 2.2, 2.3 and 2.4 of this document.

Table S4. Effect of storage on activity and selectivity of the various forms of yeast whole cells in bioreduction of 1a

\begin{tabular}{|c|c|c|c|c|c|c|c|c|c|}
\hline & & \multicolumn{2}{|c|}{ C. norvegica } & \multicolumn{2}{|c|}{ D. fabryi } & \multicolumn{2}{|c|}{ L. elongisporus } & \multicolumn{2}{|c|}{ P. carsonii } \\
\hline & & $\begin{array}{c}c_{(S)-\mathbf{1} \mathbf{a}} \\
(\%)\end{array}$ & $\begin{array}{c}e e_{(S)-2 \mathbf{a}} \\
(\%)\end{array}$ & $\begin{array}{c}c_{(S)-\mathbf{1} \mathbf{a}} \\
(\%)\end{array}$ & $\begin{array}{c}e e_{(S)-2 \mathbf{a}} \\
(\%)\end{array}$ & $\begin{array}{c}c_{(S)-\mathbf{1} \mathbf{a}} \\
(\%)\end{array}$ & $\begin{array}{c}e e_{(S)-\mathbf{2} \mathbf{a}} \\
(\%)\end{array}$ & $\begin{array}{c}c_{(S)-\mathbf{1 a}} \\
(\%)\end{array}$ & $\begin{array}{c}e e_{(S)-\mathbf{2} \mathbf{a}} \\
(\%)\end{array}$ \\
\hline \multirow{3}{*}{ Cell paste } & Fresh & $94 \pm 0.1$ & $99 \pm 0.3$ & $91 \pm 0.9$ & $>99$ & $93 \pm 0.3$ & $99 \pm 0.1$ & $94 \pm 0.8$ & $99 \pm 0.1$ \\
\hline & Stored at $4{ }^{\circ} \mathrm{C}$ (6 months) & a) & b) & a) & b) & a) & b) & a) & b) \\
\hline & Stored at $4{ }^{\circ} \mathrm{C}$ (12 months) & b) & b) & b) & b) & b) & b) & b) & b) \\
\hline \multirow{3}{*}{ Lyophilized } & Fresh & $73 \pm 0.6$ & $>99$ & $74 \pm 0.3$ & $>99$ & $92 \pm 0.7$ & $>99$ & $91 \pm 0.9$ & $>99$ \\
\hline & Stored at $4{ }^{\circ} \mathrm{C}$ (6 months) & $73 \pm 1.5$ & $>99$ & $73 \pm 2.0$ & $98 \pm 0.1$ & $91 \pm 1.8$ & $>99$ & $88 \pm 0.3$ & $>99$ \\
\hline & Stored at $4{ }^{\circ} \mathrm{C}$ (12 months) & $72 \pm 2.7$ & $>99$ & $72 \pm 2.5$ & $97 \pm$ & $90 \pm 0.8$ & $>99$ & $88 \pm 0.9$ & $>99$ \\
\hline \multirow{3}{*}{ Immobilized } & Fresh & $69 \pm 0.6$ & $>99$ & $70 \pm 0.9$ & $>99$ & $88 \pm 0.5$ & $>99$ & $87 \pm 0.2$ & $>99$ \\
\hline & Stored at $4{ }^{\circ} \mathrm{C}$ (6 months) & $67 \pm 0.5$ & $>99$ & $67 \pm 0.1$ & $>99$ & $87 \pm 0.3$ & $>99$ & $84 \pm 1.0$ & $>99$ \\
\hline & Stored at $4{ }^{\circ} \mathrm{C}$ (12 months) & $65 \pm 0.1$ & $>99$ & $66 \pm 1.0$ & $>99$ & $86 \pm 0.6$ & $>99$ & $84 \pm 0.9$ & $>99$ \\
\hline
\end{tabular}




\subsection{Acyloin condensation mediated with freshly harvested cell paste or lyophilized whole cells}

A suspension of yeast cells $(150 \mathrm{mg})$ in phosphate buffer $(5 \mathrm{~mL}, 100 \mathrm{mM}, \mathrm{pH}$ 7) was incubated with sodium pyruvate ( 2 equiv., $41.4 \mathrm{mg}$ ) in a $10 \mathrm{~mL}$ test tube at $25^{\circ} \mathrm{C}$ for $1 \mathrm{~h}$, followed by addition of a solution of benzaldehyde $(3,40 \mathrm{mM})$ in 2-propanol $(100 \mu \mathrm{l})$. The reaction was conducted with orbital shaking at $25^{\circ} \mathrm{C}$ and $750 \mathrm{rpm}$. Samples were taken after $4 \mathrm{~h}$ of reaction time, extracted with ethyl acetate $(600 \mu \mathrm{L})$ dried over $\mathrm{Na}_{2} \mathrm{SO}_{4}$ and analyzed by GC. The conversion, product distribution and enantiomeric excess of the acyloin product $(R)-\mathbf{4}$ were determined by GC as described in Section 1.2.

\subsection{Acyloin condensation mediated by immobilized yeast cells}

A suspension of immobilized yeast cell biocatalyst $(150 \mathrm{mg})$ in citrate buffer $(2.5 \mathrm{~mL}, 100 \mathrm{mM}, \mathrm{pH} 5)$ was supplemented with sodium pyruvate ( 3 equiv., $32 \mathrm{mg}$ ) in a $5 \mathrm{~mL}$ test tube at $25^{\circ} \mathrm{C}$, followed by addition of a solution of benzaldehyde $(3,40 \mathrm{mM})$ in 2-propanol $(100 \mu 1)$. The reaction was conducted with orbital shaking at $25^{\circ} \mathrm{C}$ and $750 \mathrm{rpm}$. Samples were taken after $3 \mathrm{~h}$ of reaction time, extracted with ethyl acetate $(600 \mu \mathrm{L})$ dried over $\mathrm{Na}_{2} \mathrm{SO}_{4}$ and analyzed by GC. The conversion, product distribution and enantiomeric excess of the acyloin product $(R)-\mathbf{4}$ were determined by GC as described in Section 1.2.

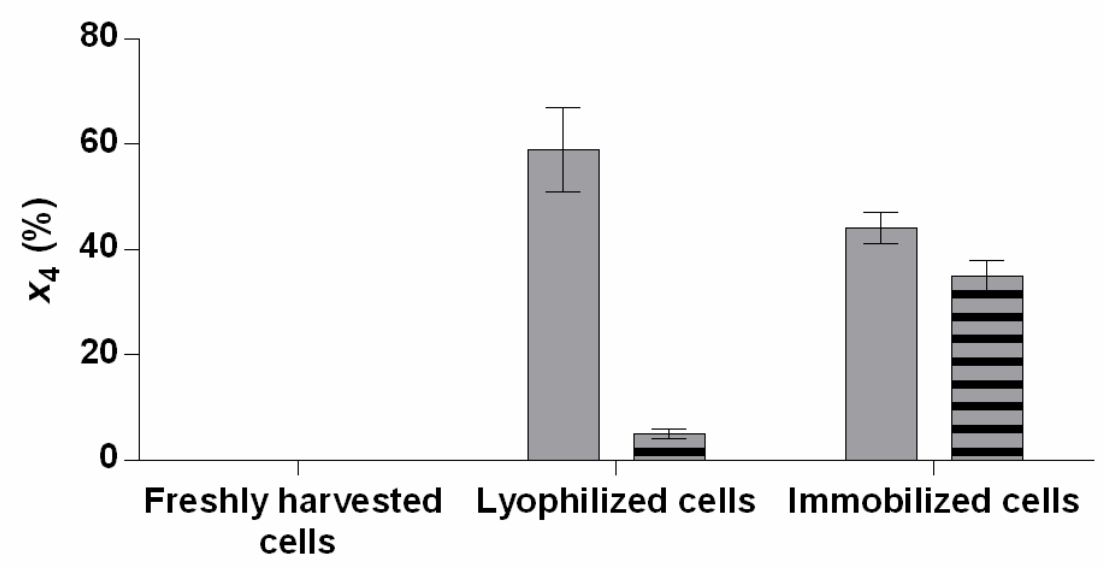

Figure S6. Recyclability of different forms of Lodderomyces elongisporus whole cells in acyloin condensation of $\mathbf{3}$ (amount of acyloin product $x_{(R)-4}$ is represented: data of first run as gray-filled bars; data of second run of biotransformation as grayfilled black striped bars.

\subsection{Switching between two types of batch mode biotransformations}

First reaction: Benzaldehyde $(\mathbf{3}, 40 \mathrm{mM})$ was subjected to acyloin condensation by the washed biocatalyst as described in Section 2.8.

Second reaction: The immobilized whole-cell biocatalyst from the first reaction was washed by phosphate buffer. Bioreduction of ketone (1a, $15 \mathrm{mM})$ was performed as described in Section 2.4. 
Table S5. Acyloin condensation from benzaldehyde 3 as the first reaction

\begin{tabular}{lcccc}
\hline \multicolumn{1}{c}{ Strain } & $c 3(\%)$ & $e e_{(R)-\mathbf{4}}(\%)$ & $R^{\mathrm{a})}$ & $x_{(R)-\mathbf{4}}(\%)^{\mathrm{b})}$ \\
\hline L. elongisporus & $92 \pm 1.5$ & $92 \pm 0.1$ & 0.95 & $44 \pm 1.3$ \\
$P$. carsonii & $90 \pm 1.0$ & $91 \pm 0.6$ & 0.04 & $5 \pm 0.6$ \\
\hline \multicolumn{2}{c}{ a) $R$ corresponds to molar ratio of acyloin $(R)-\mathbf{4}$ and alcohol $\mathbf{5}^{\text {b) }}$ Amount of $(R)-\mathbf{4}$ in the mixture, calculated from GC data }
\end{tabular}

Table S6. Enantiotope selective reduction of ketone 1a as the second reaction

\begin{tabular}{lccc}
\hline & Strain & $c \mathbf{1} \mathbf{a}(\%)$ & $e e_{(S)-\mathbf{2 a}(\%)}$ \\
\hline L. elongisporus & $44 \pm 1.4$ & $>99$ \\
P. carsonii & $52 \pm 0.7$ & $>99$ \\
\hline
\end{tabular}

\section{Biotransformations in continuous-flow mode}

Equipment used for continuous-flow biotransformations is described in detail in the Experimental Section of the main article.

\subsection{Enantiotope selective reduction of ketone 1a-d with immobilized yeast cell biocatalysts in continuous-flow mode at analytical scale}

Enantiotope selective reduction of ketone 1a-d in continuous-flow mode was performed by using SynBioCart columns filled with the immobilized whole-cells $(410 \pm 13 \mathrm{mg})$. The ketone (1a or $\mathbf{1 b}, 17$ $\mathrm{mM}$ ) was dissolved in phosphate buffer $(20 \mathrm{~mL}, 100 \mathrm{mM}, \mathrm{pH}$ 7.5) containing NADH $(0.1 \mathrm{mM})$ and 2propanol $(2 \mathrm{v} / \mathrm{v} \%)$. The column immobilized yeast cell biocatalyst was pre-washed by phosphate buffer (100 $\mu \mathrm{L} \mathrm{min}^{-1}$ for $60 \mathrm{~min}$ ) followed by pumping the substrate solution through the column at various flow rates $\left(100 \mu \mathrm{L} \mathrm{min}{ }^{-1}\right.$ and $\left.50 \mu \mathrm{L} \mathrm{min}{ }^{-1}\right)$ at $30{ }^{\circ} \mathrm{C}$. Samples were taken at different time intervals, extracted with ethyl acetate $(700 \mu \mathrm{L})$ dried over $\mathrm{Na}_{2} \mathrm{SO}_{4}$ and analyzed by $\mathrm{GC}$ as described in Section 1.2 .

Table S7. Enantiotope selective bioreduction of ketones $1 \mathbf{a}$ and $\mathbf{1 b}$ in continuous-flow mode

\begin{tabular}{cccccccc}
\hline Strain & flow rate $\left(\mu \mathrm{L} \mathrm{min}^{-1}\right)$ & $c_{\mathbf{1 a}}(\%)$ & $e e_{(S)-\mathbf{2 a}}(\%)$ & $r_{\text {flow }}$ a) & $c_{\mathbf{1 b}}(\%)$ & $e e_{(S)-2 \mathbf{b}}(\%)$ & $r_{\text {flow }}$ a) \\
\hline C. norvegica & 50 & $42 \pm 0.5$ & $>99$ & 0.9 & $49 \pm 3.2$ & $>99$ & 1.0 \\
C. norvegica & 100 & $38 \pm 0.3$ & $>99$ & 1.6 & $37 \pm 2.7$ & $>99$ & 1.5 \\
D. fabryi & 50 & $25 \pm 1.1$ & $>99$ & 0.5 & $22 \pm 2.7$ & $>99$ & 0.5 \\
D. fabryi & 100 & $21 \pm 2.6$ & $>99$ & 0.9 & $17 \pm 3.3$ & $>99$ & 0.7 \\
L. elongisporus & 50 & $92 \pm 0.9$ & $>99$ & 1.9 & $86 \pm 0.2$ & $>99$ & 1.8 \\
L. elongisporus & 100 & $85 \pm 2.8$ & $>99$ & 3.5 & $80 \pm 0.4$ & $>99$ & 3.3 \\
P. carsonii & 50 & $95 \pm 0.4$ & $>99$ & 2.0 & $93 \pm 1.6$ & $>99$ & 1.9 \\
P. carsonii & 100 & $92 \pm 0.7$ & $>99$ & 3.8 & $89 \pm 2.5$ & $>99$ & 3.7 \\
\hline
\end{tabular}

a) Specific reaction rate in the flow system $\left(r_{\text {flow }}\right)$ according to following equation: $r_{\text {flow }}=([P] \times f) / m_{\mathrm{b}}[$ where $[P]-$ concentration of the product $\left(\mu \mathrm{mol} \mathrm{mL}^{-1}\right), f$ - flow rate $\left(\mathrm{mL} \mathrm{min}^{-1}\right), m_{\mathrm{b}}$ - mass of the applied biocatalyst $\left.(\mathrm{g})\right]^{4}$ 
Table S8. Enantiotope selective bioreduction of ketones $\mathbf{1 c}$ and $\mathbf{1 d}$ in continuous-flow mode at different flow rates.

\begin{tabular}{|c|c|c|c|c|c|c|c|}
\hline Strain & flow rate $\left(\mu \mathrm{L} \min ^{-1}\right)$ & $c_{1 \mathrm{c}}(\%)$ & $e e(S)-2 \mathrm{c}(\%)$ & $r_{\text {flow }}{ }^{\text {a) }}$ & $c_{1 d}(\%)$ & $e e(S)-2 \mathrm{~d}(\%)$ & $r$ flow $^{\text {a) }}$ \\
\hline C. norvegica & 50 & $43 \pm 2.2$ & $>99$ & 0.9 & $44 \pm 0.4$ & $>99$ & 0.9 \\
\hline C. norvegica & 100 & $39 \pm 2.3$ & $>99$ & 1.6 & $36 \pm 1.2$ & $>99$ & 1.5 \\
\hline D. fabryi & 50 & $37 \pm 3.2$ & $>99$ & 0.8 & $44 \pm 2.1$ & $>99$ & 0.9 \\
\hline D. fabryi & 100 & $31 \pm 3.6$ & $>99$ & 1.3 & $36 \pm 2.6$ & $>99$ & 1.5 \\
\hline L. elongisporus & 50 & $63 \pm 2.5$ & $>99$ & 1.3 & $96 \pm 1.3$ & $>99$ & 2.0 \\
\hline L. elongisporus & 100 & $51 \pm 1.1$ & $>99$ & 2.1 & $95 \pm 2.8$ & $>99$ & 3.9 \\
\hline P. carsonii & 50 & $78 \pm 0.9$ & $>99$ & 1.6 & $84 \pm 2.0$ & $>99$ & 1.7 \\
\hline P. carsonii & 100 & $72 \pm 1.4$ & $>99$ & 3.0 & $81 \pm 4.0$ & $>99$ & 3.4 \\
\hline
\end{tabular}

\subsection{Enantiotope selective reduction of ketone 1a-d with immobilized yeast cell biocatalysts in continuous-flow mode at preparative scale}

Enantiotope selective reduction of ketone 1a-d in continuous-flow mode was performed by using SynBioCart columns filled with the immobilized whole-cells (410 $\pm 13 \mathrm{mg})$. The ketone (1a-d), $17 \mathrm{mM})$ was dissolved in phosphate buffer $(100 \mathrm{~mL}, 100 \mathrm{mM}, \mathrm{pH} 7.5)$ containing NADH $(0.1 \mathrm{mM})$ and 2propanol $(2 \mathrm{v} / \mathrm{v} \%)$. The packed column was pre-washed by phosphate buffer $\left(100 \mu \mathrm{L} \mathrm{min}^{-1}\right.$ for $\left.60 \mathrm{~min}\right)$ followed by pumping the substrate solution through the column $\left(50 \mu \mathrm{L} \mathrm{min}^{-1}, 24 \mathrm{~h}\right)$ at $30{ }^{\circ} \mathrm{C}$. Samples were taken at different time intervals, extracted with ethyl acetate $(700 \mu \mathrm{L})$ dried over $\mathrm{Na}_{2} \mathrm{SO}_{4}$ and analyzed by GC as described in Section 1.2

The product was isolated from the effluent collected during stationary phase of the operation by extraction with ethyl acetate $(2 \times 60 \mathrm{~mL})$, drying over $\mathrm{Na}_{2} \mathrm{SO}_{4}$ and concentration under reduced pressure. The residue was purified by plate chromatography (silica gel, eluent: hexane - ethyl acetate, 10:4) to yield the corresponding secondary alcohol $(S)$-2a-d.

(S)-2a: yield: $91 \%$; ee: >99\% (by GC); colorless liquid; IR (film): 3356, 2986, 1453, 1116, 1078, 936, 740, 697 and $504 \mathrm{~cm}^{-1} ;{ }^{1} \mathrm{H}-\mathrm{NMR}\left(\mathrm{CDCl}_{3}, 300 \mathrm{MHz}\right) \delta \mathrm{ppm}: 1.27$ (d, $\left.J=6.02 \mathrm{~Hz}, 3 \mathrm{H} \mathrm{CH}_{3}\right) ; 1.80(\mathrm{~s}, 1 \mathrm{H}$, $\mathrm{OH}) ; 2.71-2.84\left(\mathrm{~m}, 2 \mathrm{H}, \mathrm{CH}_{2}\right) ; 4.07$ (m, 1H, CH) 7.29-7.36 (m, 5H, Ar-H); ${ }^{13} \mathrm{C}-\mathrm{NMR}\left(\mathrm{CDCl}_{3}, 75 \mathrm{MHz}\right)$ $\delta$ ppm: $22.83\left(\mathrm{CH}_{3}\right), 45.85(\mathrm{CH}), 98.91(\mathrm{CH}), 126.06$ (Ar-C), 128.59 (Ar-C), 129.45 (Ar-C), 130.60 (Ar-C); Elemental analysis for $\mathrm{C}_{9} \mathrm{H}_{12} \mathrm{O}$ : required: $\mathrm{C} 79.37, \mathrm{H} 8.88$, found $\mathrm{C} 79.52, \mathrm{H} 8.93$. ${ }^{1} \mathrm{H}$ NMR and ${ }^{13} \mathrm{C}$ NMR spectra were in accordance with literature data. ${ }^{2}$

(S)-2b: yield: $88 \%$; ee: >99\% (by GC); colorless liquid IR (film): 3341, 2959, 2928, 2873, 1459, 1375, 1122, 1060, $950 \mathrm{~cm}^{-1} ;{ }^{1} \mathrm{H}-\mathrm{NMR}\left(\mathrm{CDCl}_{3}, 300 \mathrm{MHz}\right) \delta \mathrm{ppm}: 0.91$ (t, $\left.J=6.0 \mathrm{~Hz}, 3 \mathrm{H}, \mathrm{CH}_{3}\right), 1.20(\mathrm{~d}, J=6.2$ $\left.\mathrm{Hz}, 3 \mathrm{H}, \mathrm{CH}_{3}\right), 1.24-1.55\left(\mathrm{~m}, 8 \mathrm{H}, 4 \times \mathrm{CH}_{2}\right), 1.6(\mathrm{~s}, 1 \mathrm{H}, \mathrm{OH}), 3.82(\mathrm{~m}, 1 \mathrm{H}, \mathrm{CH}) ;{ }^{13} \mathrm{C}-\mathrm{NMR}\left(\mathrm{CDCl}_{3}, 75\right.$ MHz) $\delta$ ppm: $14.06\left(\mathrm{CH}_{3}\right), 22.67\left(\mathrm{CH}_{2}\right), 23.57\left(\mathrm{CH}_{3}\right), 25.48\left(\mathrm{CH}_{2}\right), 31.88\left(\mathrm{CH}_{2}\right), 39.37\left(\mathrm{CH}_{2}\right), 68.22$ $(\mathrm{CH})$; Elemental analysis for $\mathrm{C}_{7} \mathrm{H}_{16} \mathrm{O}$ : required: $\mathrm{C} 72.35, \mathrm{H} 13.88$, found $\mathrm{C} 72.19, \mathrm{H}$ 13.94. ${ }^{1} \mathrm{H}$ NMR and ${ }^{13} \mathrm{C}$ NMR spectra were in accordance with literature data. ${ }^{2}$ 
(S)-2c: yield: $63 \%$; ee: >99\% (by GC); colorless liquid IR (film): 3331, 2972, 1449, 1075, 1009, 897, 759, $697 \mathrm{~cm}^{-1} ;{ }^{1} \mathrm{H}-\mathrm{NMR}\left(\mathrm{CDCl}_{3}, 300 \mathrm{MHz}\right) \delta \mathrm{ppm}: 1.52\left(\mathrm{~d}, J=6.4 \mathrm{~Hz}, 3 \mathrm{H}, \mathrm{CH}_{3}\right), 2.00(\mathrm{~s}, 1 \mathrm{H}, \mathrm{OH})$, 4.88-4.95 (m, 1H, CH), 7.28-7.39 (m, 5H, Ar-H); ${ }^{13} \mathrm{C}-\mathrm{NMR}\left(\mathrm{CDCl}_{3}, 75 \mathrm{MHz}\right) \delta \mathrm{ppm:} 25.19\left(\mathrm{CH}_{3}\right)$, $70.45(\mathrm{CH}), 125.43(\mathrm{Ph}), 127.51(\mathrm{Ph}), 128.54(\mathrm{Ph}), 146.6(\mathrm{Ph})$. Elemental analysis for $\mathrm{C}_{7} \mathrm{H}_{16} \mathrm{O}$ : required: C 78.65, H 8.25, found C 78.19, H 8.94. ${ }^{1} \mathrm{H}$ NMR and ${ }^{13} \mathrm{C}$ NMR spectra were in accordance with literature data. ${ }^{2}$

(S)-2d: yield: $90 \%$; ee: >99\% (by GC); colorless liquid IR (film): 3357, 2965, 2926, 2860, 1495, 1453, 1127, 1054, 744, $697 \mathrm{~cm}^{-1}$; ${ }^{1} \mathrm{H}-\mathrm{NMR}\left(\mathrm{CDCl}_{3}, 300 \mathrm{MHz}\right) \delta \mathrm{ppm}: 1.26\left(\mathrm{~d}, \mathrm{~J}=6.2 \mathrm{~Hz}, 3 \mathrm{H}, \mathrm{CH}_{3}\right), 1.55$ (s, $1 \mathrm{H}, \mathrm{OH}), 1,79-1.82\left(\mathrm{~m}, 2 \mathrm{H}, \mathrm{CH}_{2}\right), 2.65-2.84\left(\mathrm{~m}, 2 \mathrm{H}, \mathrm{CH}_{2}\right), 3.81-3.91(\mathrm{~s}, \mathrm{H}, \mathrm{CH}), 7.19-7.34(\mathrm{~m}, 5 \mathrm{H}, \mathrm{Ar}-$ H). 13C-NMR (CDCl 3 , $75 \mathrm{MHz}) \delta$ ppm: $23.67\left(\mathrm{CH}_{3}\right), 32.18\left(\mathrm{CH}_{2}\right), 40.90\left(\mathrm{CH}_{2}\right), 67.55(\mathrm{CH}), 125.87$ $(\mathrm{Ph}), 128.45(\mathrm{Ph}), 142.07(\mathrm{Ph})$. Elemental analysis for $\mathrm{C}_{10} \mathrm{H}_{14} \mathrm{O}$ : required: $\mathrm{C} 79.96, \mathrm{H} \mathrm{10.65}$, found $\mathrm{C}$ 79.61, $\mathrm{H}$ 10.29. ${ }^{1} \mathrm{H}$ NMR and ${ }^{13} \mathrm{C}$ NMR spectra were in accordance with literature data. ${ }^{5}$

\subsection{Recovery of the NADH-containing reaction medium}

The NADH-containing reaction medium was recovered from the effluent collected from the continuousflow bioreduction of ketone 1a-d as described in Section 3.2 during the stationary phase of the operation. The collected effluent was extracted with ethyl acetate $(2 \times 60 \mathrm{~mL})$. The organic solvent traces were removed from the NADH-containing aqueous under reduced pressure $\left(30^{\circ} \mathrm{C}, 153 \mathrm{mbar}\right)$. In a subsequent run, after washing the column by phosphate buffer (100 $\mu \mathrm{L} \mathrm{min}^{-1}$ for $\left.60 \mathrm{~min}\right)$, the ketone (1a-d, $17 \mathrm{mM})$ was dissolved in recycled phosphate buffer $(100 \mathrm{~mL}, 100 \mathrm{mM}, \mathrm{pH}$ 7.5) containing recovered NADH and supplemented with 2-propanol ( $2 \mathrm{v} / \mathrm{v} \%)$. The resulted solution was pumped through the column $\left(50 \mu \mathrm{L} \mathrm{min}^{-1}, 24 \mathrm{~h}\right)$ at $30^{\circ} \mathrm{C}$. Samples were taken at different time intervals, extracted with ethyl acetate $(700 \mu \mathrm{L})$ dried over $\mathrm{Na}_{2} \mathrm{SO}_{4}$ and analyzed by $\mathrm{GC}$ as described in Section 1.2. 

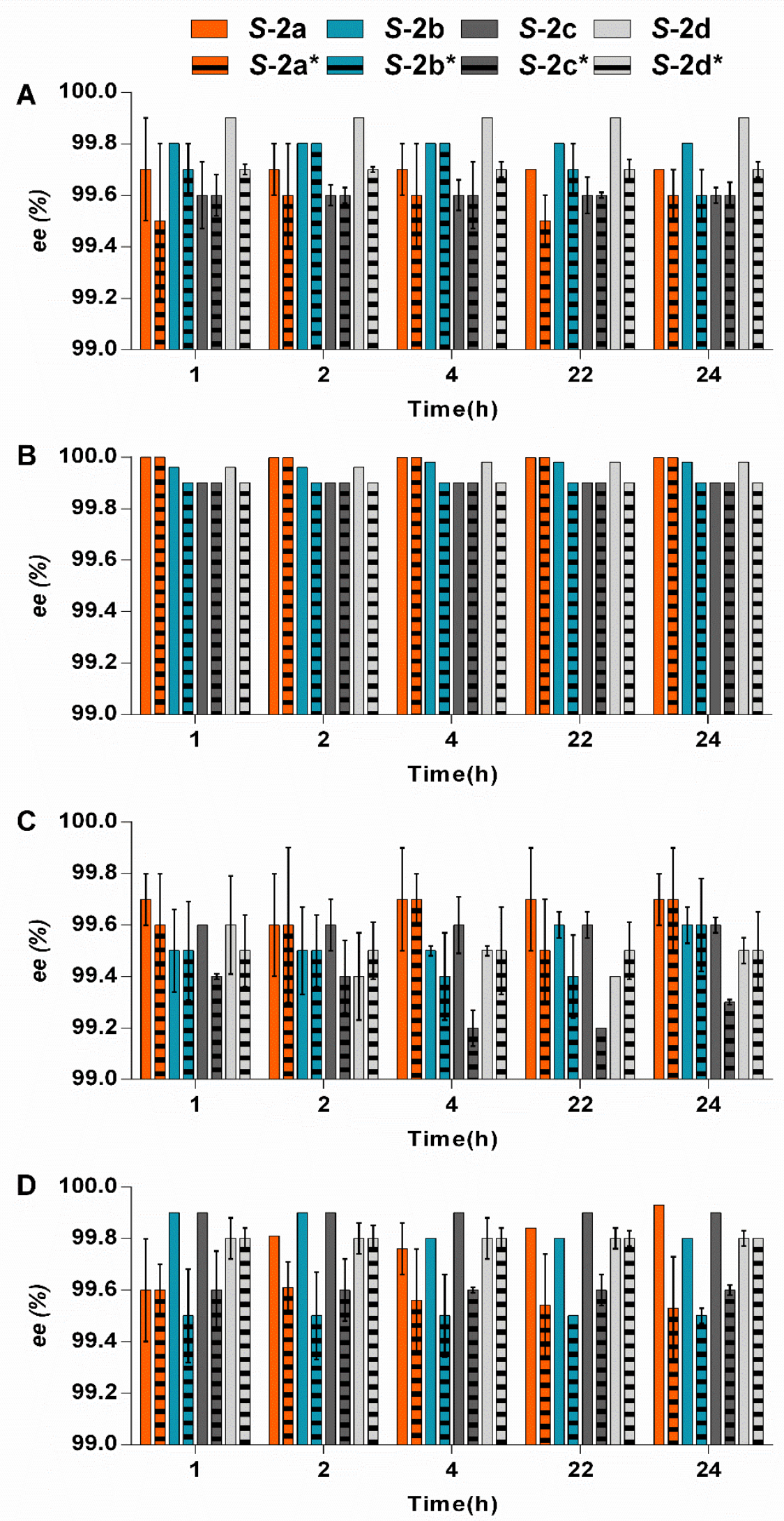

Figure S7. Comparison of selectivity in long term operation of the immobilized whole-cell biocatalysts in continuous-flow in bioreduction. Enantiomeric excess of products $(S)$-2a-d obtained in presence of fresh NADH (color-filled bars) or in presence of recovered NADH (19*-d*, black striped color-filled bars) with immobilized P. carsonii [Panel A], L. elongisporus [Panel B], C. norvegica [Panel C] and D. fabryi [Panel D] are represented. 


\subsection{Acyloin condensation of benzaldehyde 3 using immobilized yeast cells at analytical scale}

Acyloin condensation of benzaldehyde $\mathbf{3}$ in continuous-flow mode was performed by using SynBioCart columns filled with the immobilized whole-cells $(410 \pm 13 \mathrm{mg})$ after washing with citrate buffer (100 $\mu \mathrm{L} \mathrm{min}^{-1}$ for $\left.60 \mathrm{~min}\right)$. A solution of benzaldehyde $3(20 \mathrm{mM})$ and 2-propanol (400 $\left.\mu \mathrm{L}\right)$ was added to citrate buffer (20 mL, $100 \mathrm{mM}$, pH 5.0) containing sodium pyruvate (60 mM, 3 equiv.), TPP ( 0.2 $\mathrm{mM})$ and $\mathrm{MgCl}_{2}(1.0 \mathrm{mM})$ and the resulted solution was pumped through the column at $25^{\circ} \mathrm{C}$ applying a various flow rates $\left(100 \mu \mathrm{L} \mathrm{min}{ }^{-1}\right.$ and $\left.50 \mu \mathrm{L} \mathrm{min}^{-1}\right)$. Samples were taken at different time intervals, extracted with ethyl acetate $(700 \mu \mathrm{L})$ dried over $\mathrm{Na}_{2} \mathrm{SO}_{4}$ and analyzed by $\mathrm{GC}$ as described in Section 1.2 .

Table S9. Acyloin condensation of benzaldehyde 3 mediated by immobilized yeast cell-based biocatalysts at different flow rates.

\begin{tabular}{lcccccc}
\hline \multicolumn{1}{r}{ Strain name } & $\begin{array}{c}\text { flow rate } \\
(\mu \mathrm{L} \mathrm{min})\end{array}$ & $\begin{array}{c}c_{3} \\
(\%)\end{array}$ & $\begin{array}{c}e e_{(R)-4} \\
(\%)\end{array}$ & $R^{\text {a) }}$ & $\begin{array}{c}x_{(R)-4^{\mathrm{b})}} \\
(\%)\end{array}$ & $r_{\text {flow }}^{\mathrm{c})}$ \\
\hline P. carsonii & 50 & $69 \pm 4.3$ & $90 \pm 1.6$ & 0.4 & $19 \pm 0.4$ & 0.5 \\
P. carsonii & 100 & $59 \pm 3.9$ & $91 \pm 0.5$ & 0.3 & $15 \pm 2.7$ & 0.7 \\
L. elongisporus & 50 & $98 \pm 1.8$ & $96 \pm 0.8$ & 1.0 & $51 \pm 2.3$ & 1.2 \\
L. elongisporus & 100 & $81 \pm 2.5$ & $94 \pm 1.1$ & 0.7 & $37 \pm 1.8$ & 1.8 \\
\hline
\end{tabular}

${ }^{\text {a) }} R$ corresponds to molar ratio of acyloin $(R)-\mathbf{4}$ and alcohol 5 . ${ }^{\text {b) }}$ Amount of $(R)-\mathbf{4}$ in the mixture, calculated by GC. ${ }^{\text {c) }}$ Specific reaction rate in the flow system $\left(r_{\text {flow }}\right)$ according to following equation: $r_{\text {flow }}=([P] \times f) / m_{\mathrm{b}}$ [where $[P]-$ concentration of the product $\left(\mu \mathrm{mol} \mathrm{mL}^{-1}\right), f-$ flow rate $\left(\mathrm{mL} \min ^{-1}\right), m_{\mathrm{b}}-$ mass of the applied biocatalyst $\left.(\mathrm{g})\right] .^{[4]}$

\subsection{Acyloin condensation of benzaldehyde 3 using immobilized yeast cells at preparative scale}

Acyloin condensation of benzaldehyde 3 in continuous-flow mode was performed by using SynBioCart columns filled with the immobilized whole-cells $(410 \pm 13 \mathrm{mg})$ as described in Section 3.4.

The products were isolated from the effluent collected during stationary phase of the operation by extraction with ethyl acetate $(2 \times 60 \mathrm{~mL})$, drying over $\mathrm{Na}_{2} \mathrm{SO}_{4}$ and concentration under reduced pressure. The residue was purified by plate chromatography (silica gel, eluent: dichloromethane - methanol 95:5) to yield the corresponding secondary hydroxyketone $(R)-\mathbf{4}$.

(R)-4: yield: 41\%; ee: 96\% (by GC); colorless oil; IR (film): 3651, 3508, 3440, 3074, 3037, 2860, 1740, 1356, and $1178 \mathrm{~cm}^{-1} ;{ }^{1} \mathrm{H}-\mathrm{NMR}\left(\mathrm{CDCl}_{3}, 400 \mathrm{MHz}\right) \delta \mathrm{ppm}: 2.10\left(\mathrm{~s}, 3 \mathrm{H}, \mathrm{CH}_{3}\right), 4.36(\mathrm{~d}, J=5.1 \mathrm{~Hz}, 1 \mathrm{H}$, $\mathrm{OH}), 5.11(\mathrm{~d}, J=4.2 \mathrm{~Hz}, \mathrm{H}, \mathrm{CH}), 7.20-7.35$ (m, 5H, Ar-H); ${ }^{13} \mathrm{C}-\mathrm{NMR}\left(\mathrm{CDCl}_{3}, 101 \mathrm{MHz}\right) \delta \mathrm{ppm}: 25.28$ $\left(\mathrm{CH}_{3}\right), 80.01(\mathrm{CH}), 127.37$ (Ar-C), 128.76 (Ar-C), 129.04 (Ar-C), 137.97 (Ar-C), $207.14(\mathrm{C}=\mathrm{O})$; Elemental analysis for $\mathrm{C}_{9} \mathrm{H}_{10} \mathrm{O}_{2}$ : required: $\mathrm{C} 71.98, \mathrm{H}$ 6.71, found: $\mathrm{C} 72.09, \mathrm{H} 6.75$. ${ }^{1} \mathrm{H}$ NMR and ${ }^{13} \mathrm{C}$ NMR spectra were in accordance with literature data. ${ }^{6}$ 


\subsection{On demand switchable biotransformations under continuous-flow conditions}

The consecutive sequence involving three Runs of different biotransformations under continouous-flow conditions by using a single SynBioCart column filled with the corresponding immobilized whole-cell biocatalyst (L. elongisporus or P. carsonii) is described in the Experimental Section of the main article.
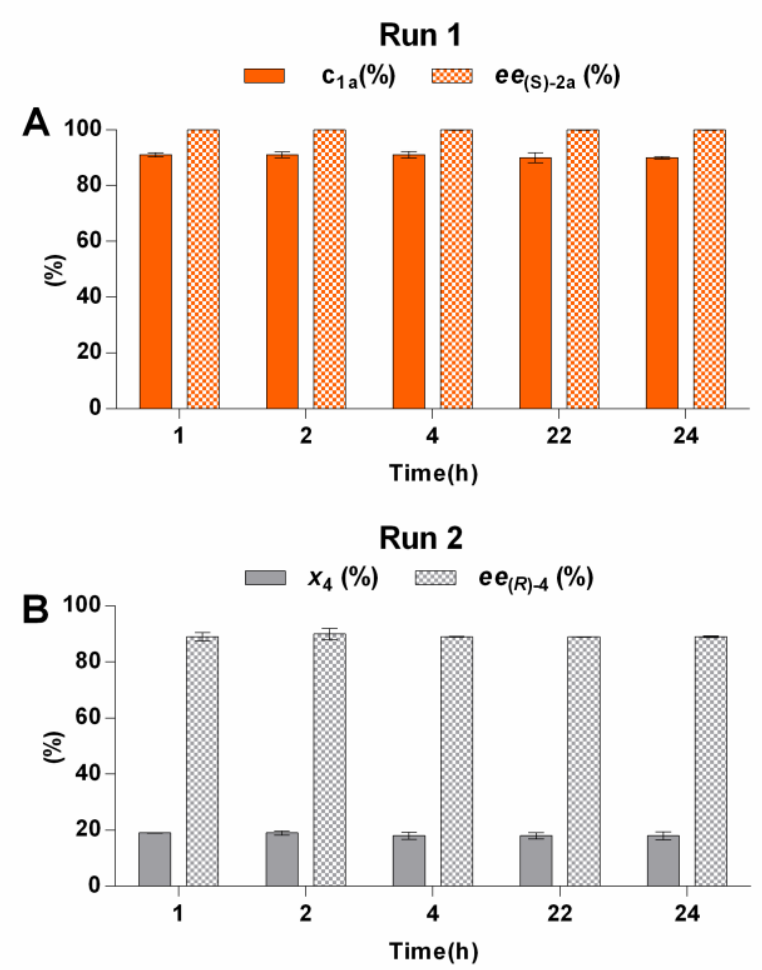

Run 3

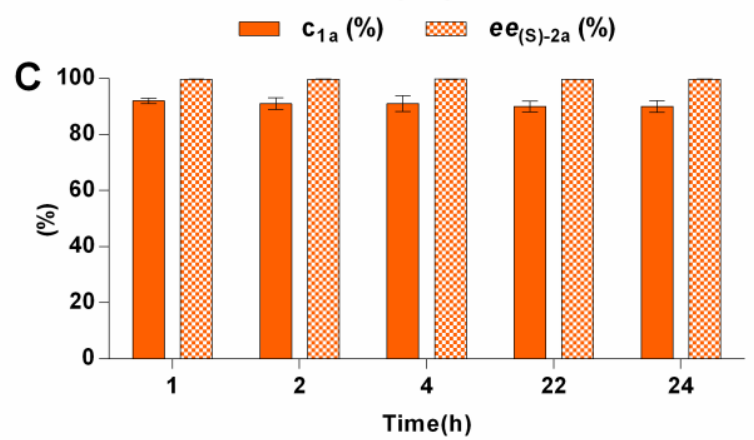

Figure S8. Operational stability of the immobilized $P$. carsonii cell-based biocatalyst in switchable continuous-flow biotransformations. Panel A: Run 1, conversion c $\mathbf{1 a}$ (orange color-filled bars) and enantiomeric excess of the product $e e_{(S)-2 a}$ (orange dotted bars) for bioreduction from 1a. Panel B: Run 2, amount of acyloin product $x_{4}$ (grey color-filled bars) and its enantiomeric excess $e e_{(R)-4}$ (grey dotted bars) for acyloin condensation of 3. Panel C: Run 3, conversion $c_{1 \mathbf{a}}$ (orange color-filled bars) and enantiomeric excess of the product $e e(S)-2 \mathbf{a}$ (orange dotted bars) for bioreduction from $1 \mathbf{a}$. 
4. NMR spectra of products and GC analysis of biotransformation products on chiral phase

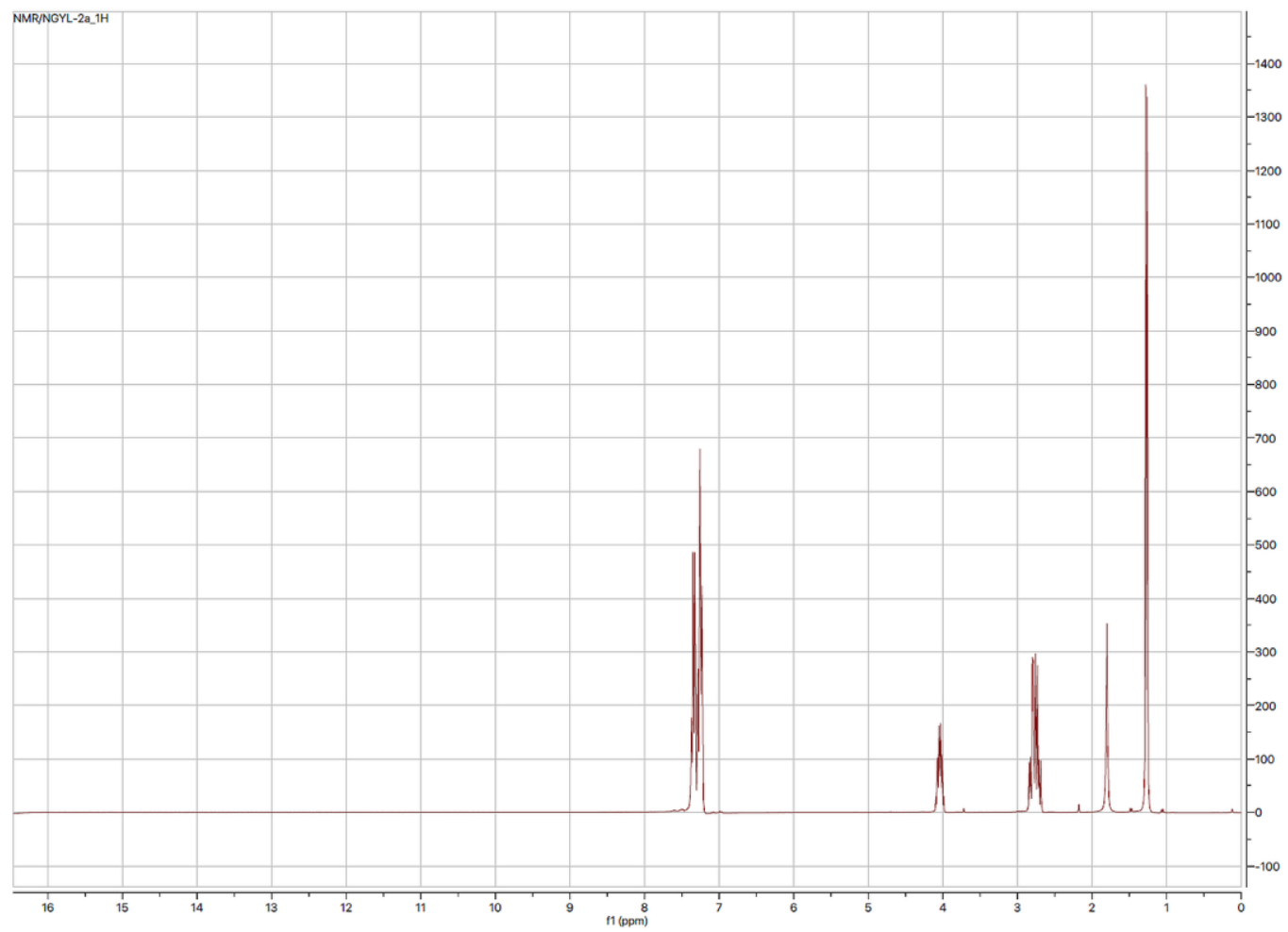

Figure S9. ${ }^{1} \mathrm{H}-\mathrm{NMR}$ spectrum of $(S)$-2a

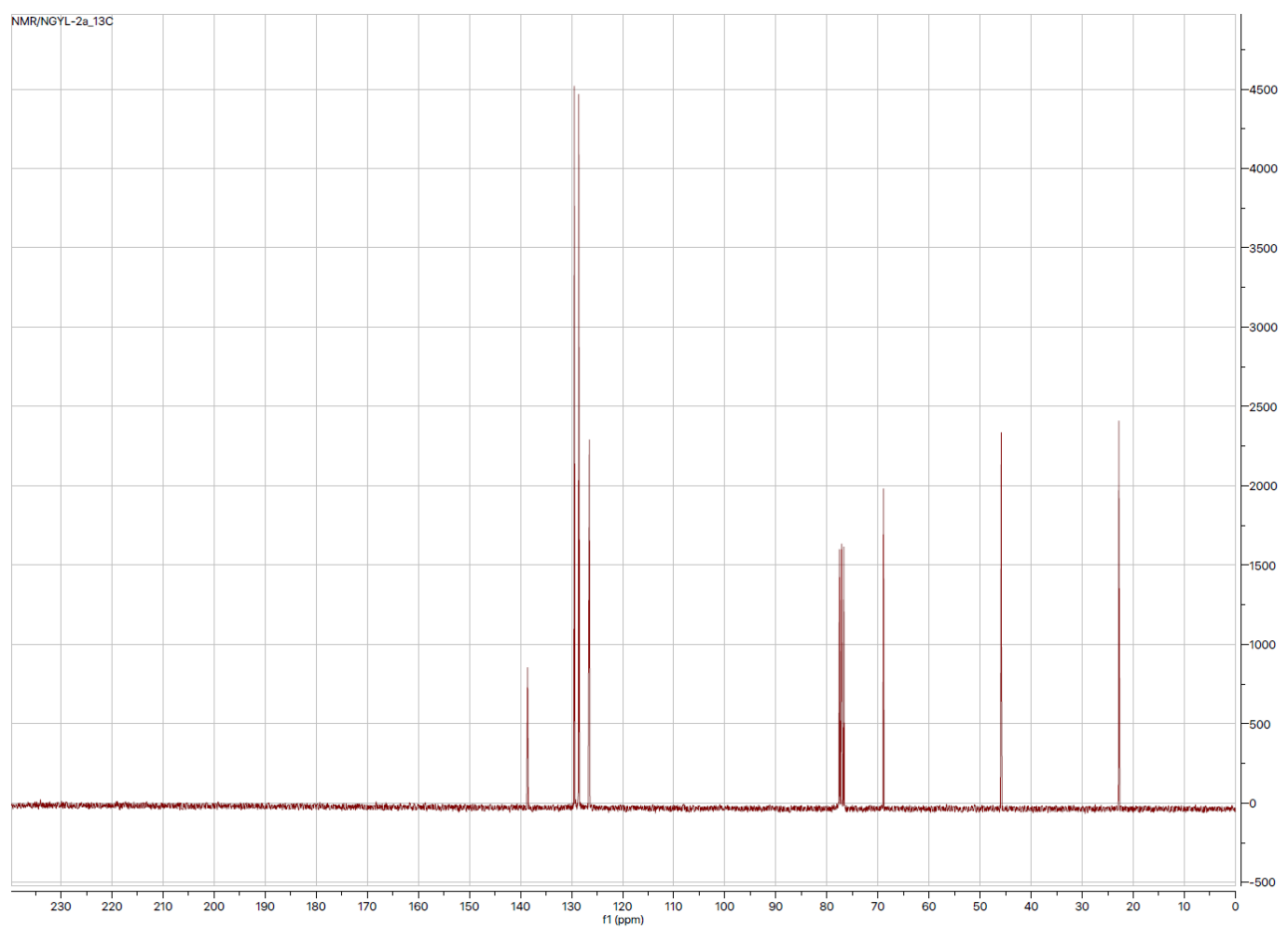

Figure S10. ${ }^{13} \mathrm{C}-\mathrm{NMR}$ spectrum of $(S)-\mathbf{2 a}$ 


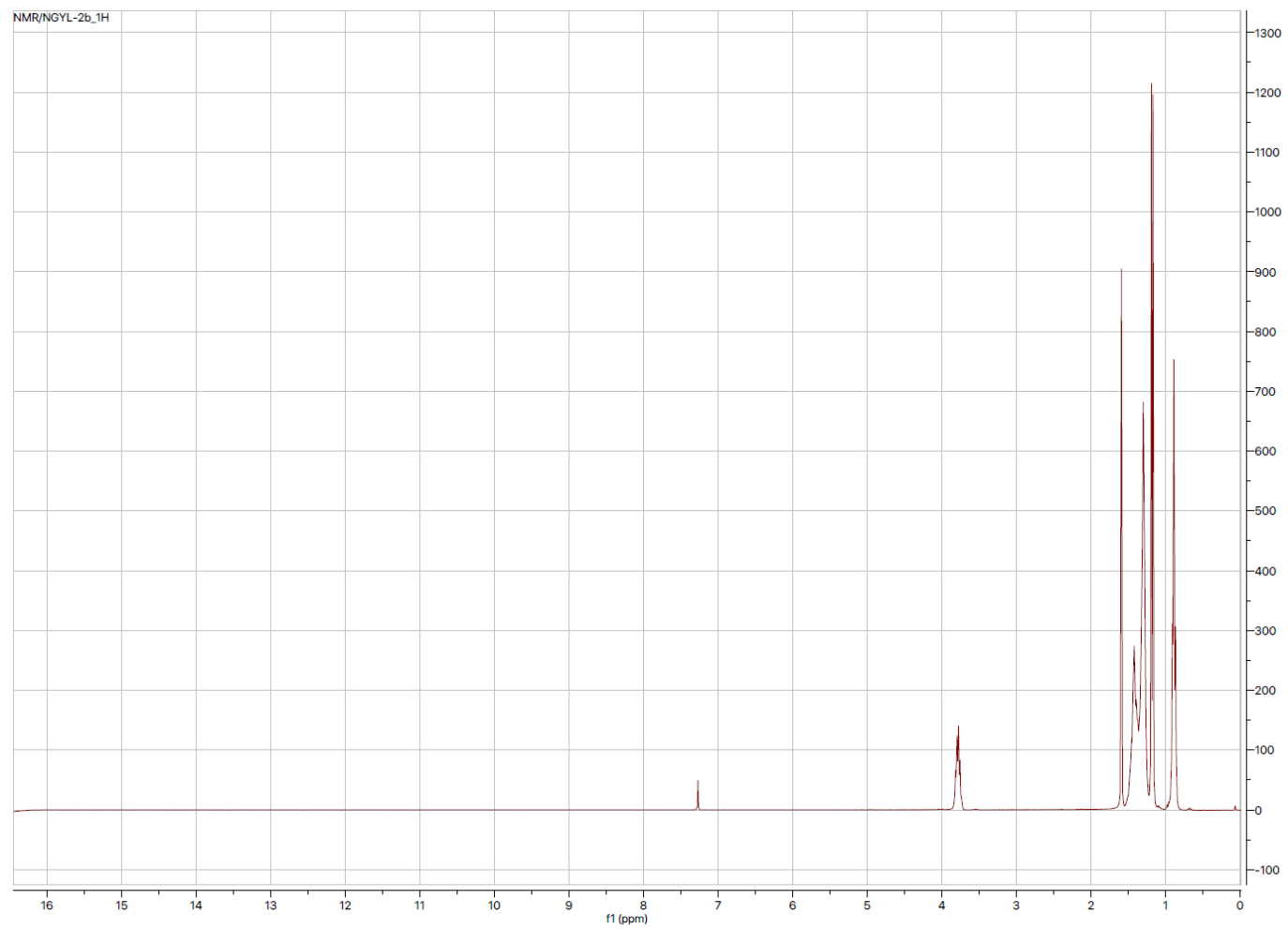

Figure S11. ${ }^{1} \mathrm{H}-\mathrm{NMR}$ spectrum of $(S)$-2b

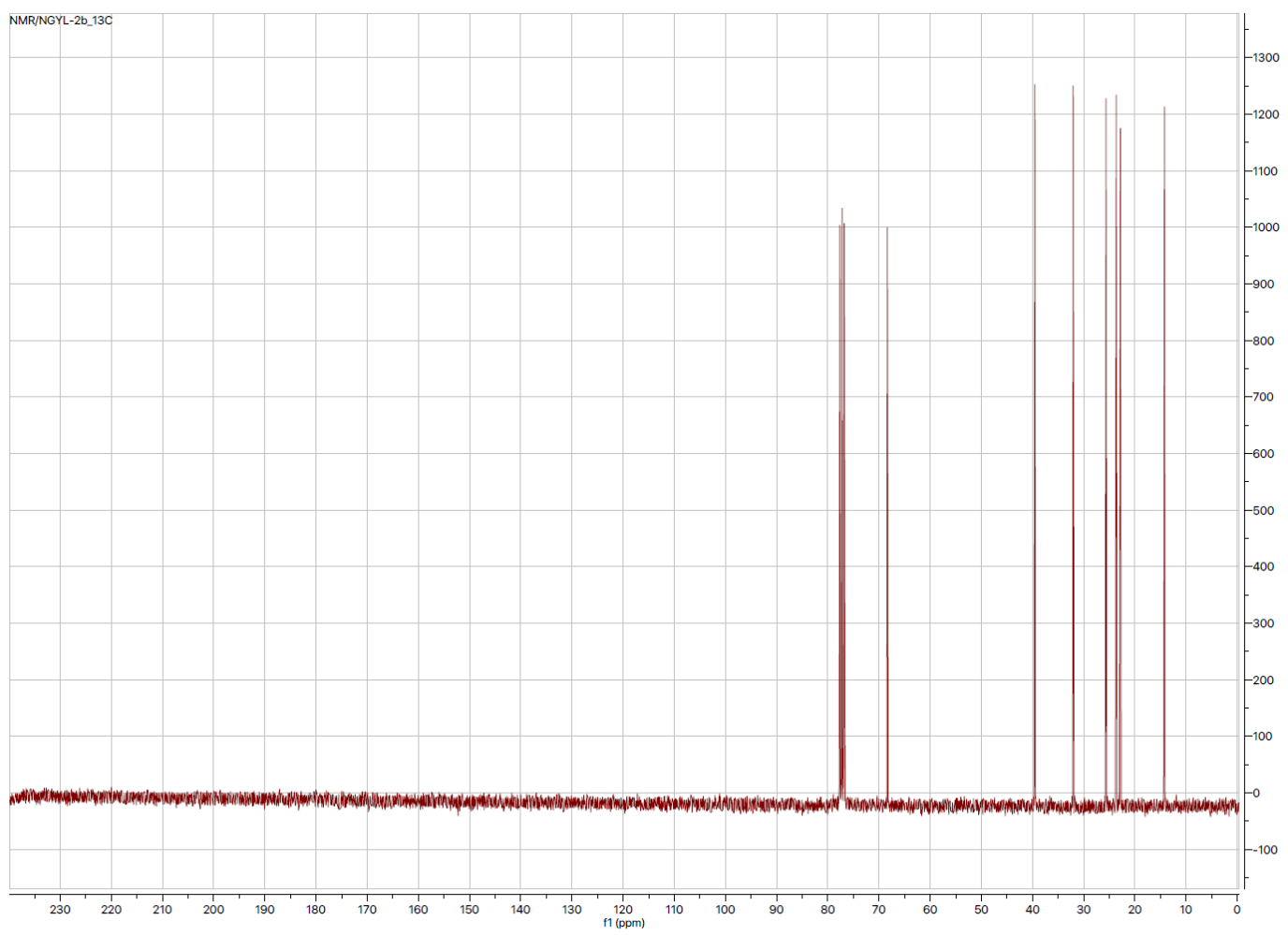

Figure S12. ${ }^{13} \mathrm{C}-\mathrm{NMR}$ spectrum of $(S)-\mathbf{2 b}$ 


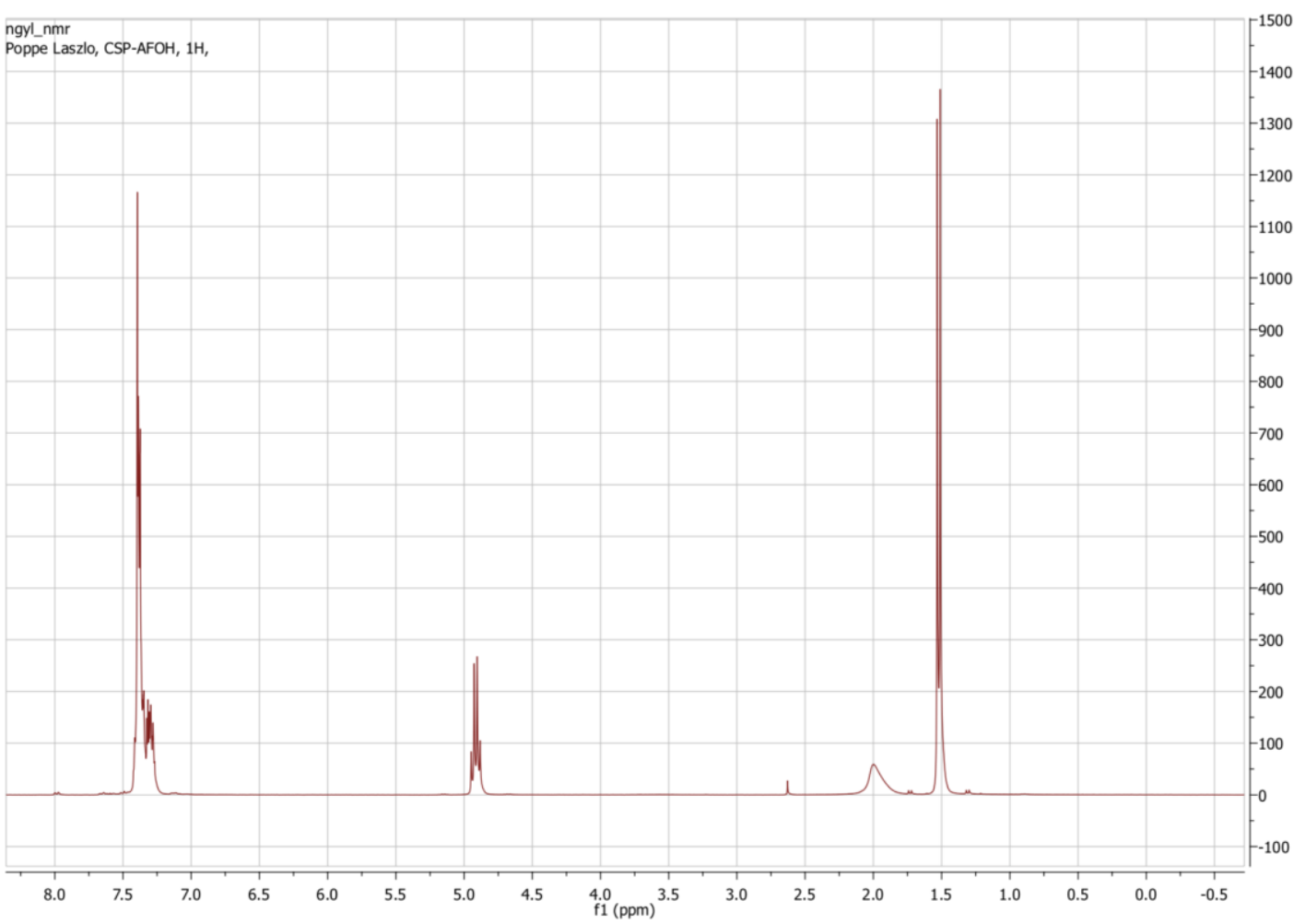

Figure S13. ${ }^{1} \mathrm{H}-\mathrm{NMR}$ spectrum of $(S)$-2c

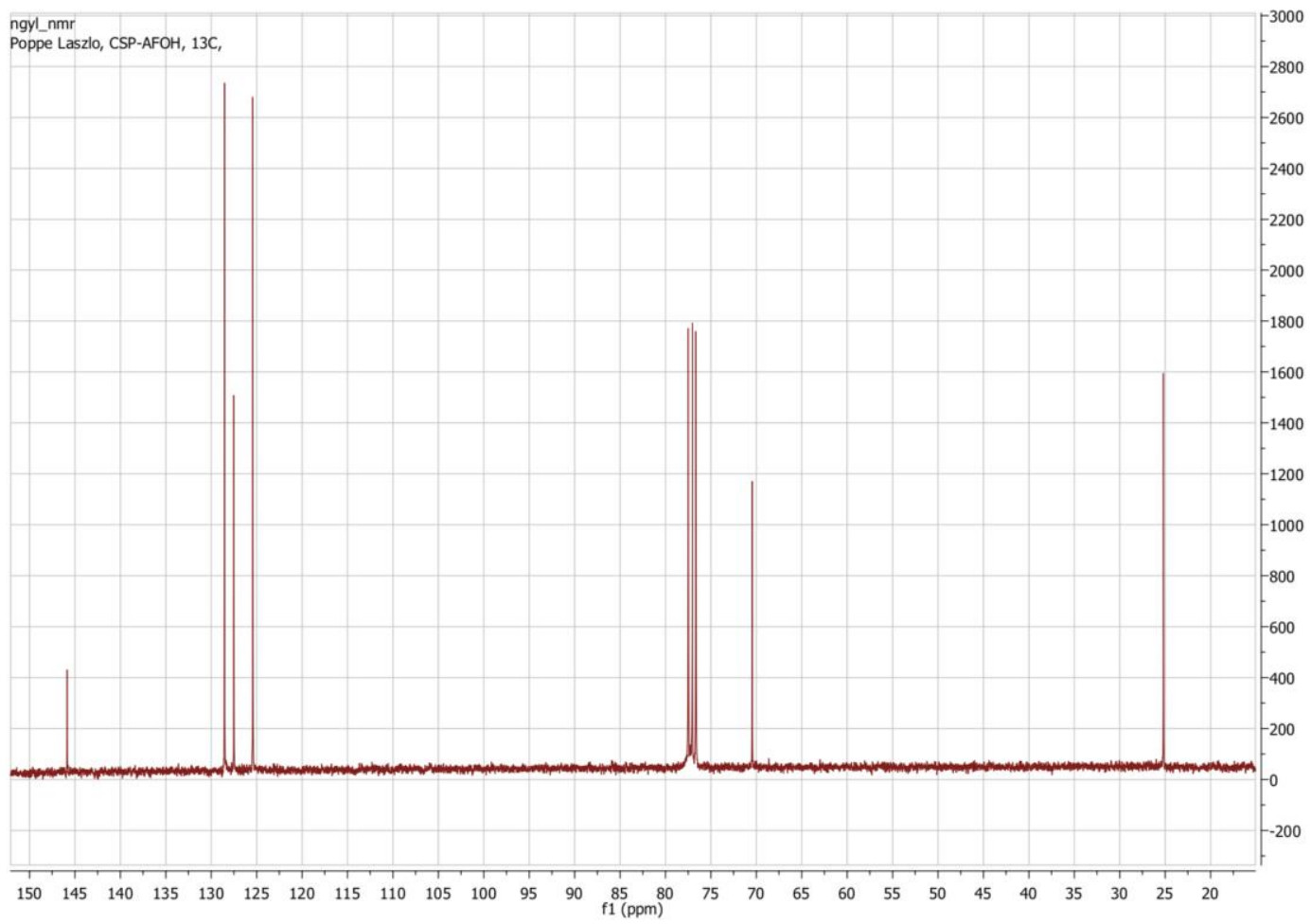

Figure S14. ${ }^{13} \mathrm{C}-\mathrm{NMR}$ spectrum of $(S)$-2c 


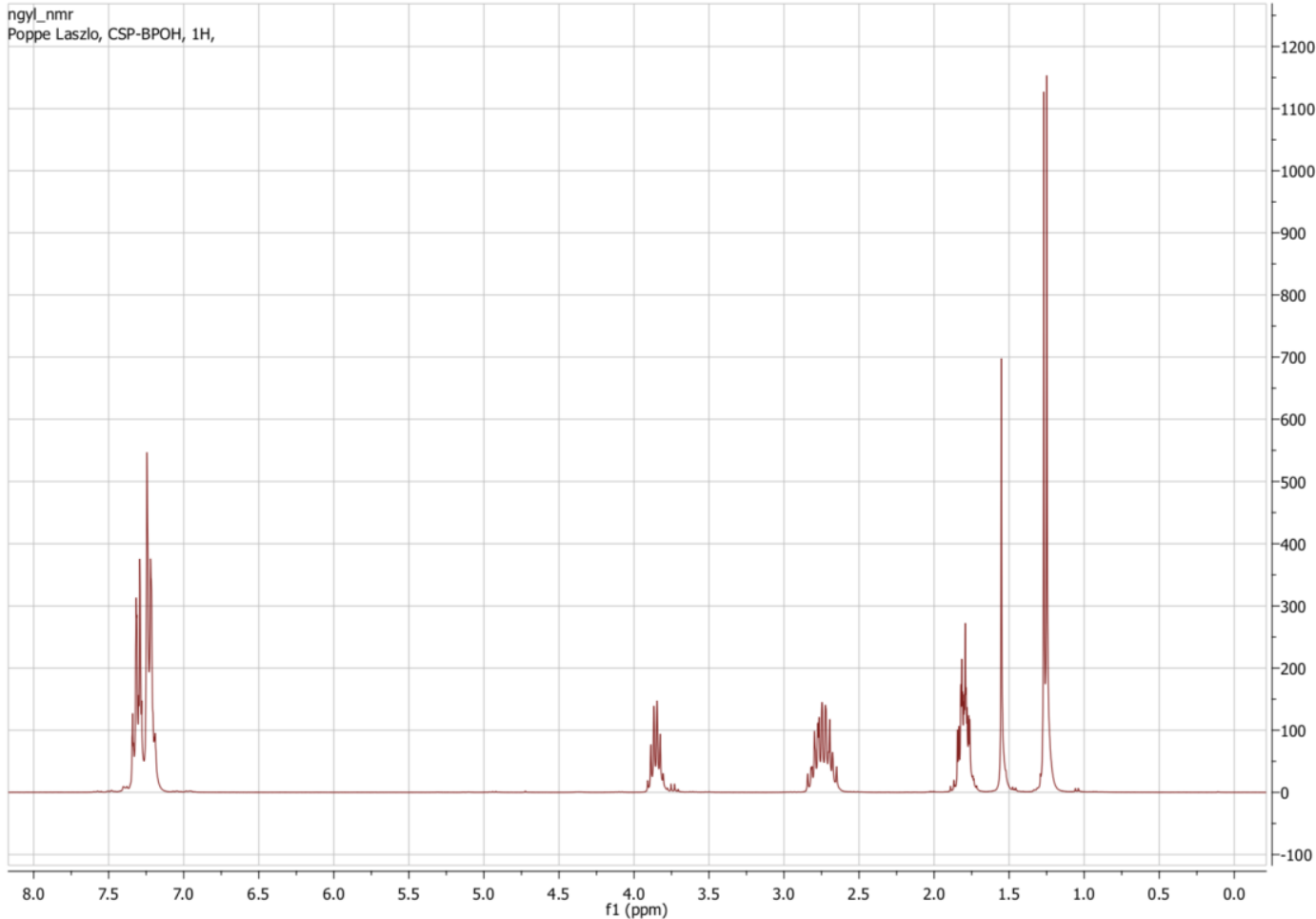

Figure S15. ${ }^{1} \mathrm{H}-\mathrm{NMR}$ spectrum of $(S)$-2d

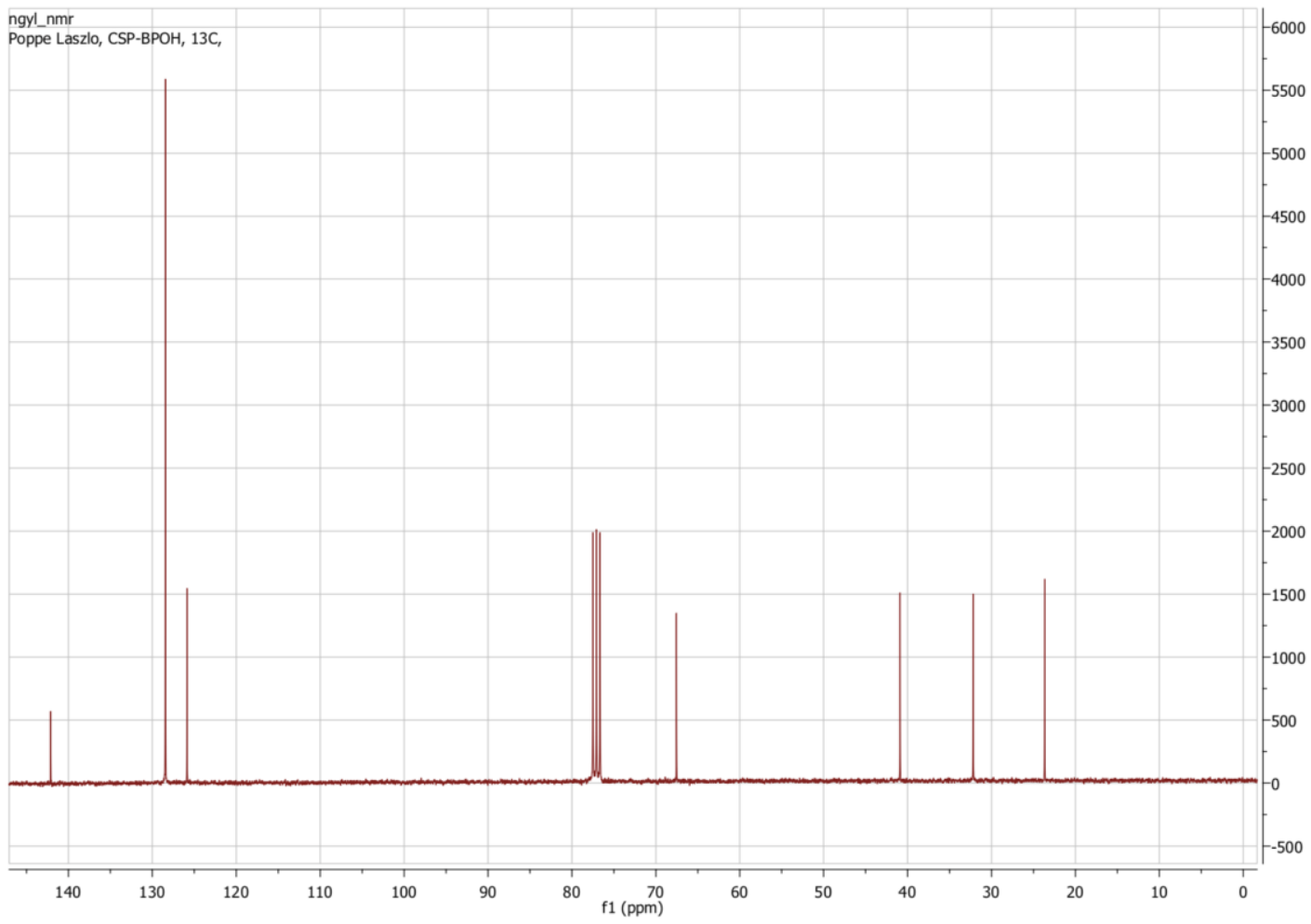

Figure S16. ${ }^{13} \mathrm{C}-\mathrm{NMR}$ spectrum of $(S)$-2d 


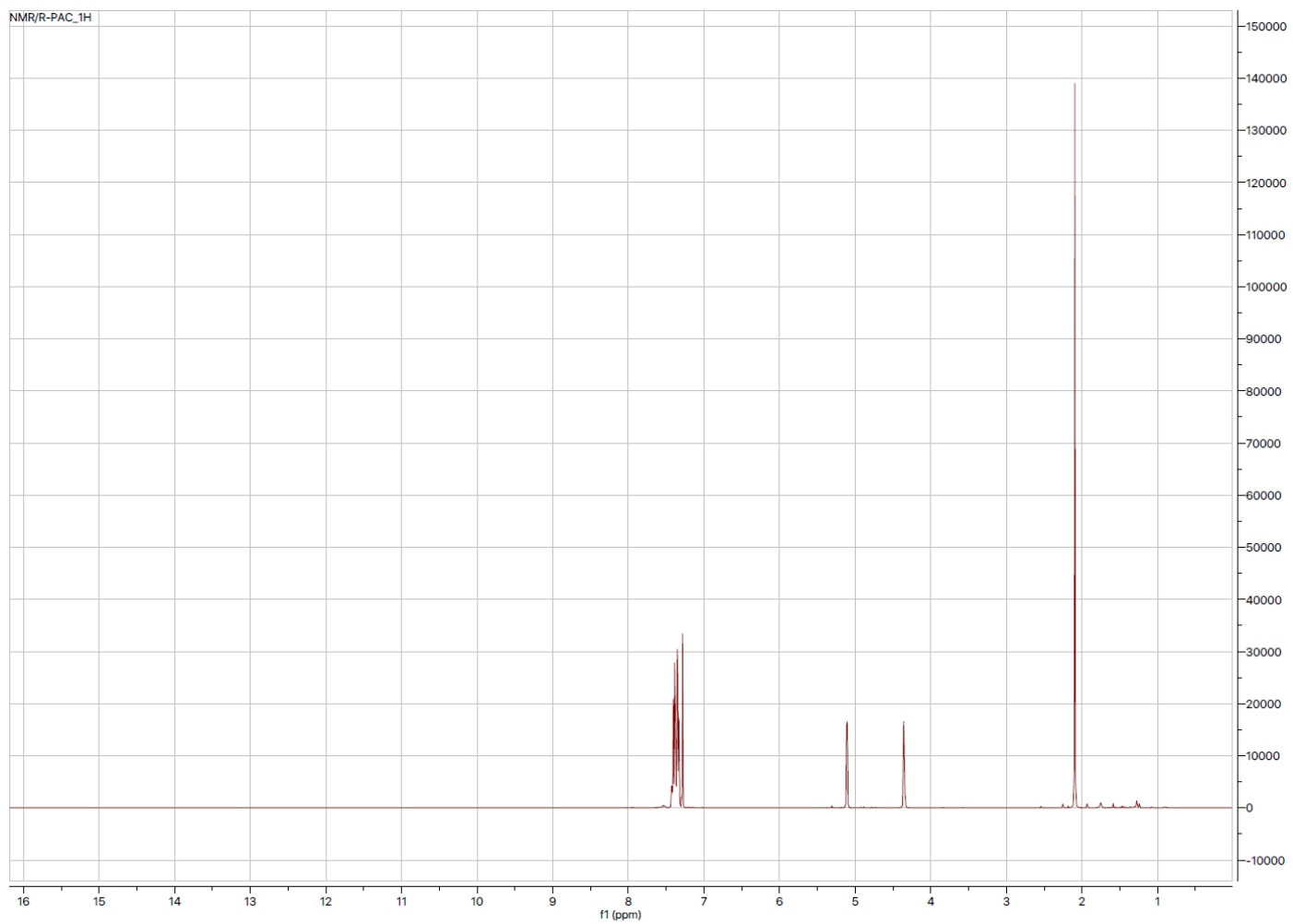

Figure S17. ${ }^{1} \mathrm{H}-\mathrm{NMR}$ spectrum of $(R)-4$

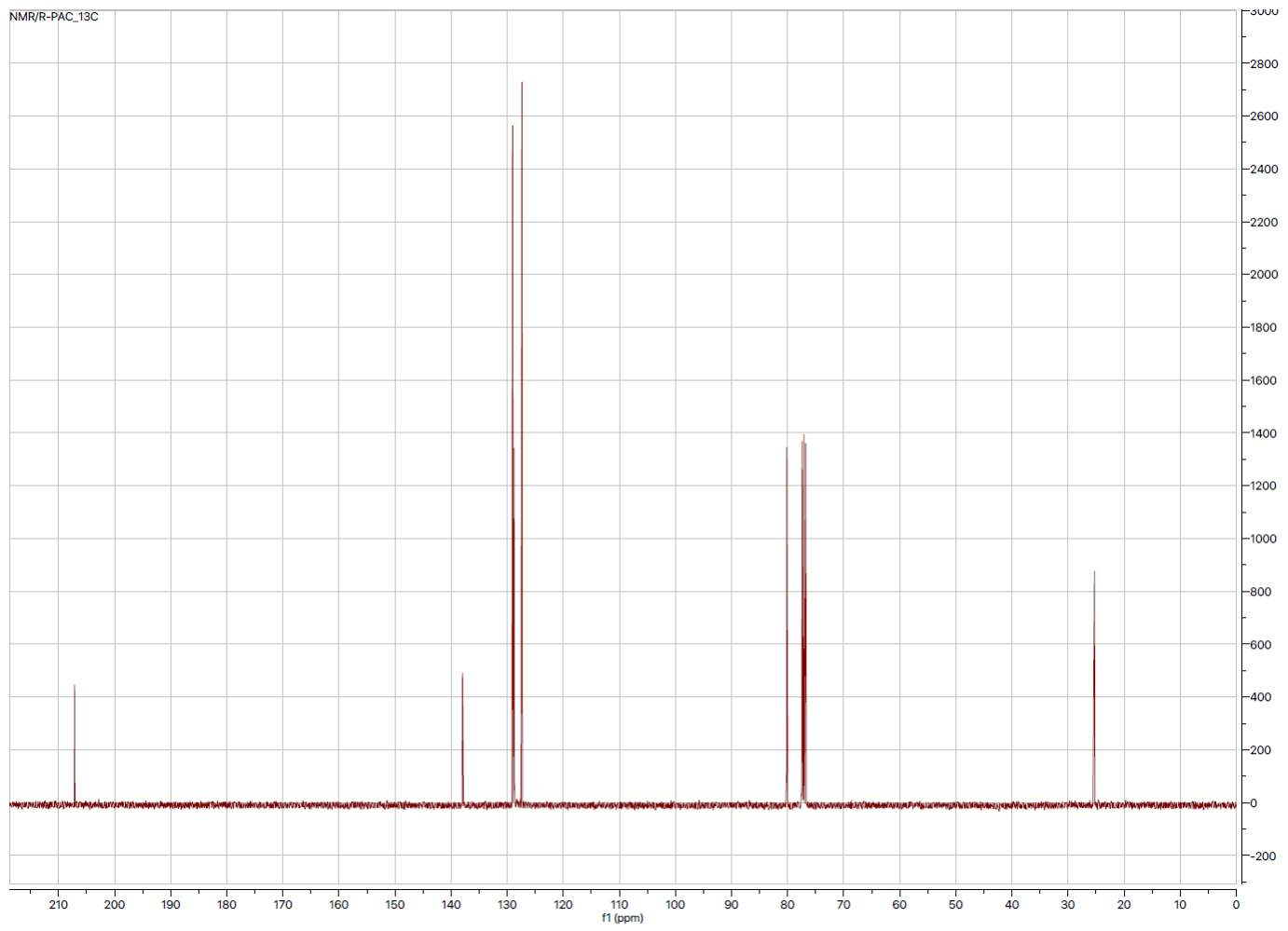

Figure S18. ${ }^{13} \mathrm{C}-\mathrm{NMR}$ spectrum of $(R)-4$ 


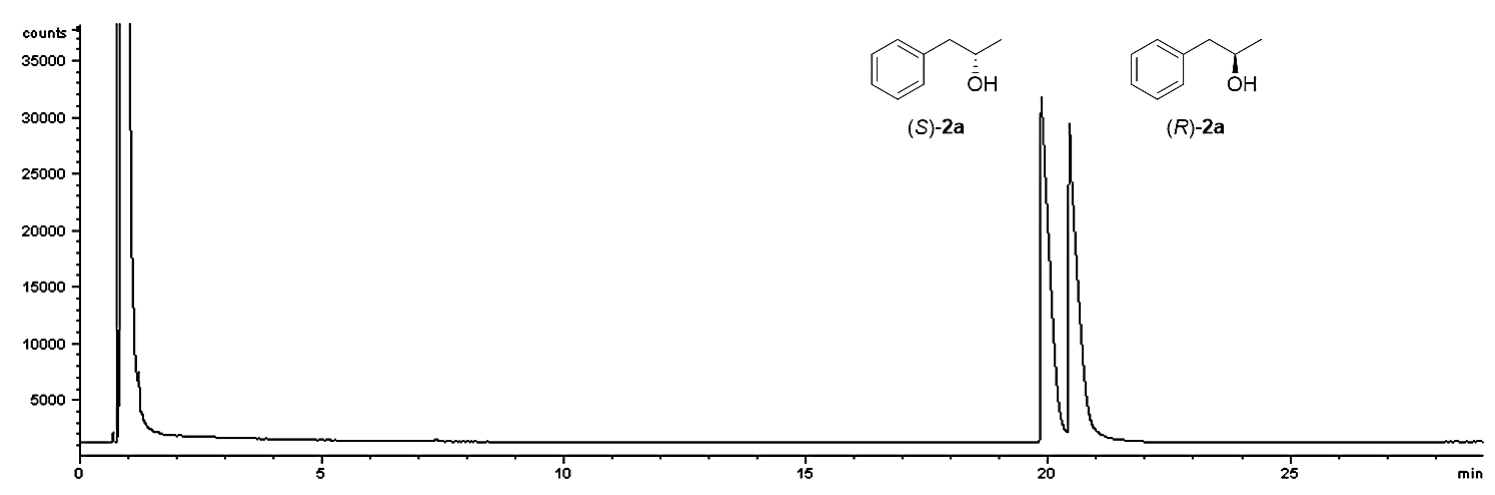

Figure S19. Reference GC chromatogram of $( \pm)-\mathbf{2 a}$

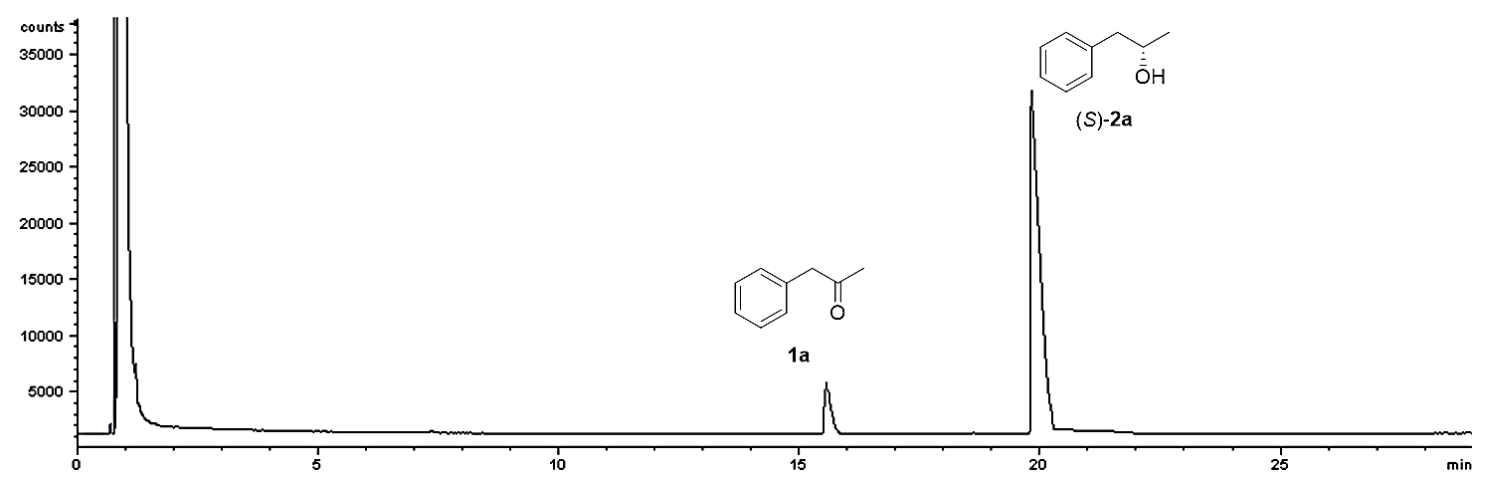

Figure S20. GC analysis of the continuous-flow bioreduction of $1 \mathbf{a}$ with immobilized yeast cell biocatalyst

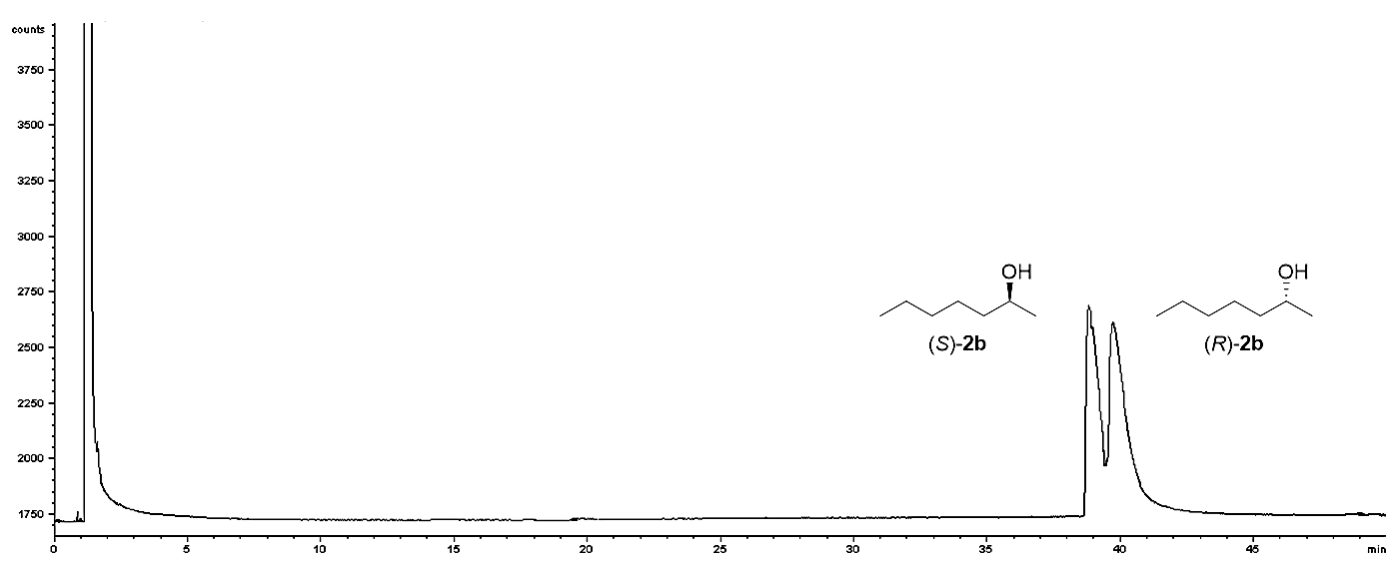

Figure S21. Reference GC chromatogram of ( \pm )-2b

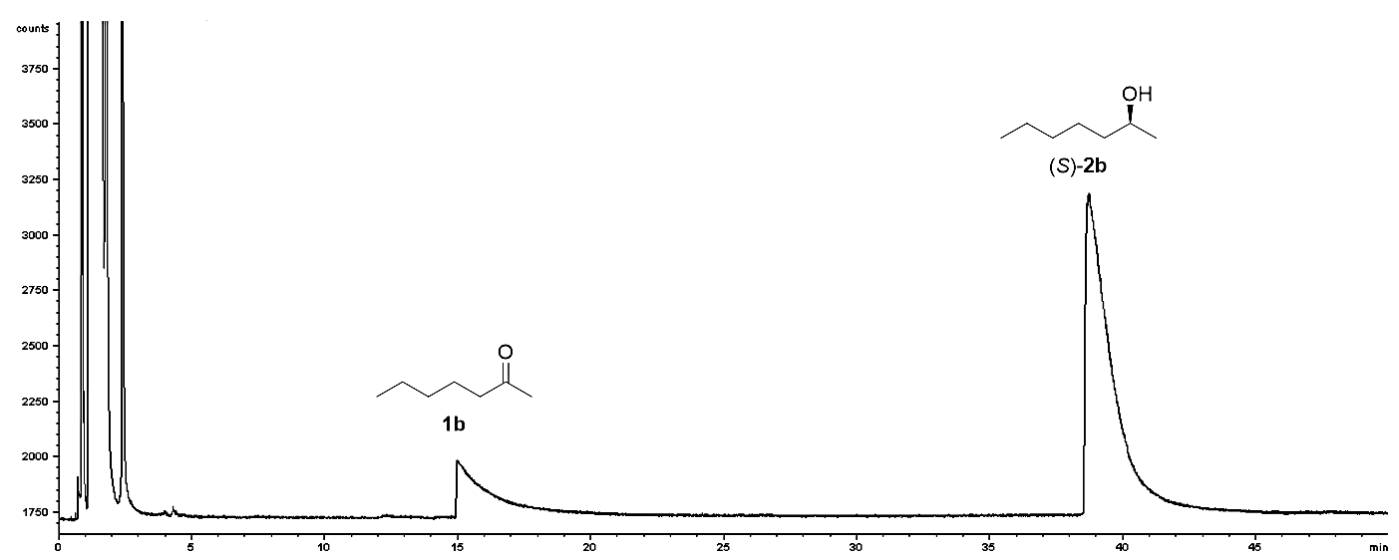

Figure S22. GC analysis of the continuous-flow bioreduction of $\mathbf{1 b}$ with immobilized yeast cell biocatalyst 


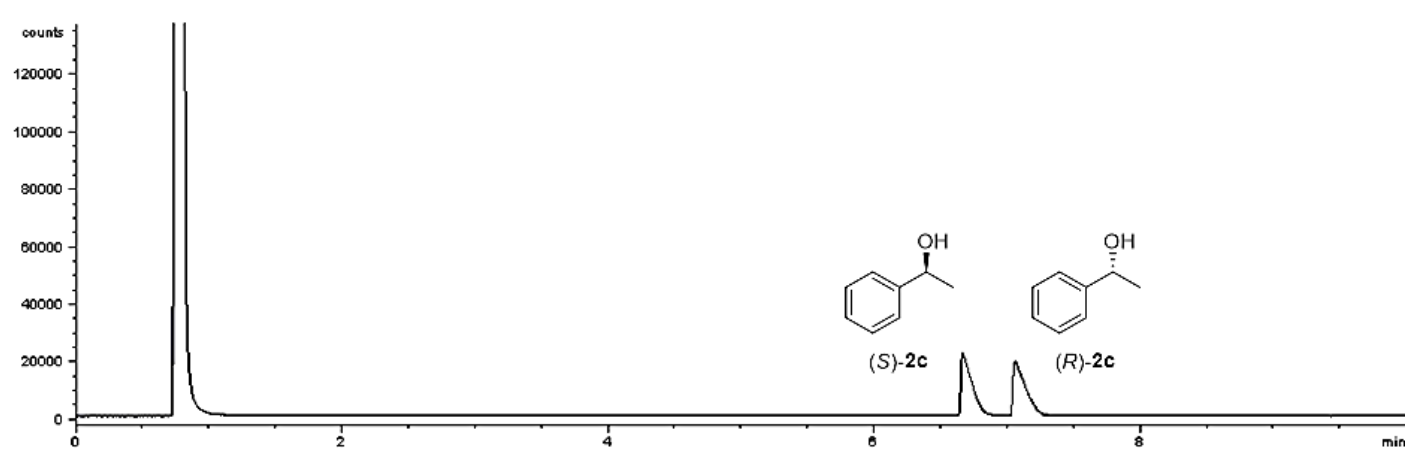

Figure S23. Reference GC chromatogram of ( \pm )-2c

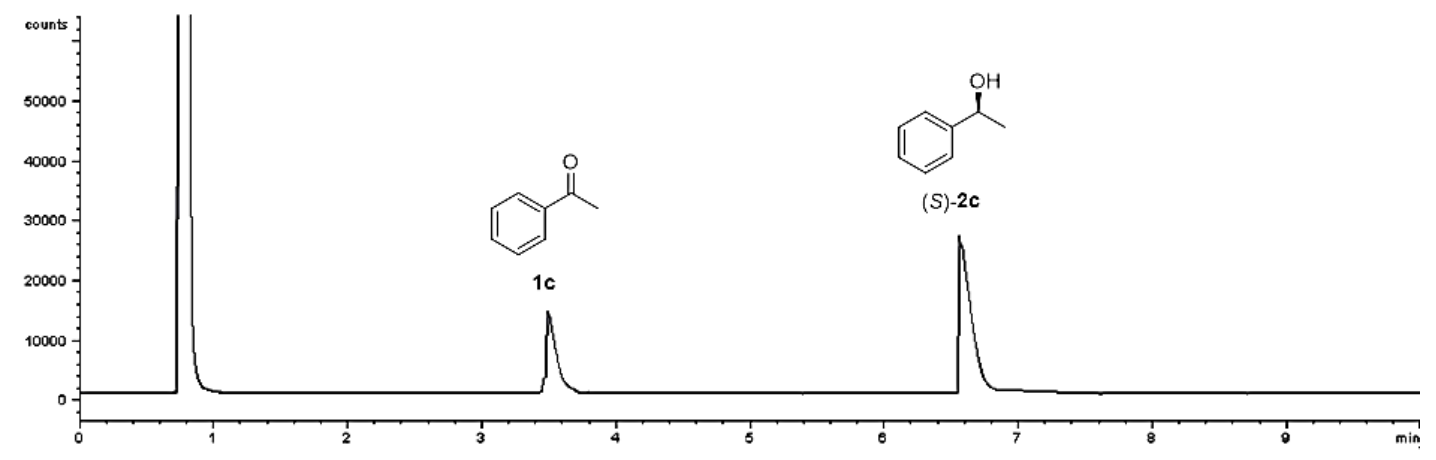

Figure S24. GC analysis of the continuous-flow bioreduction of 1c with immobilized yeast cell biocatalyst

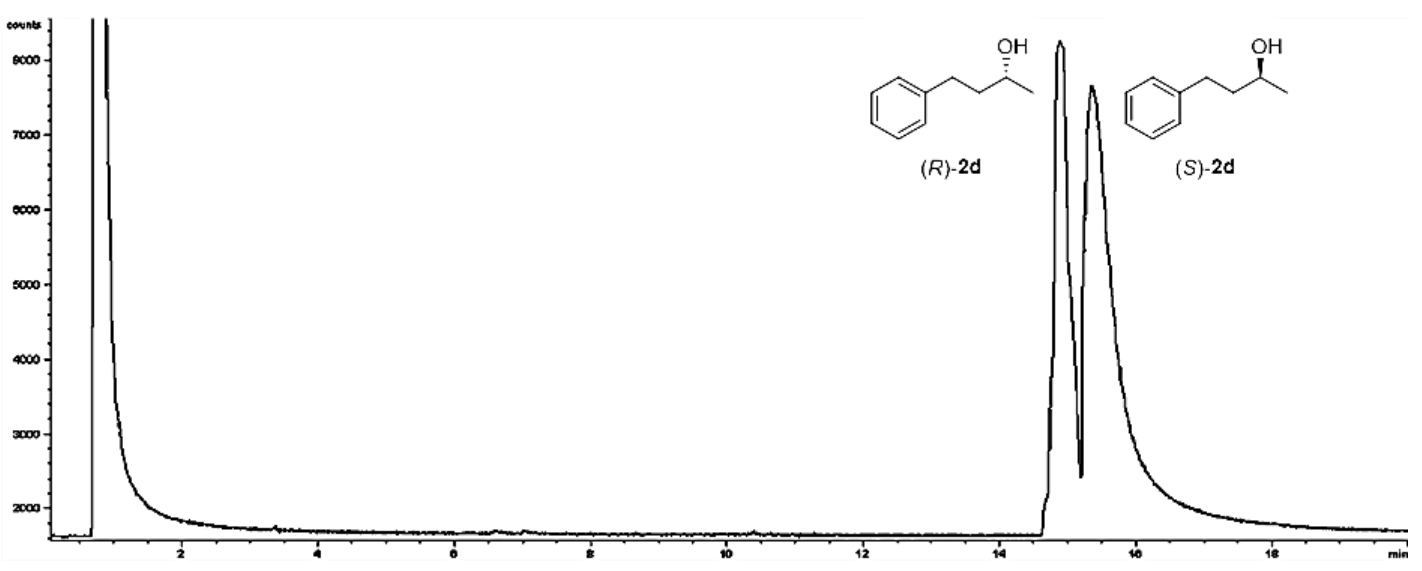

Figure S25. Reference GC chromatogram of ( \pm )-2d

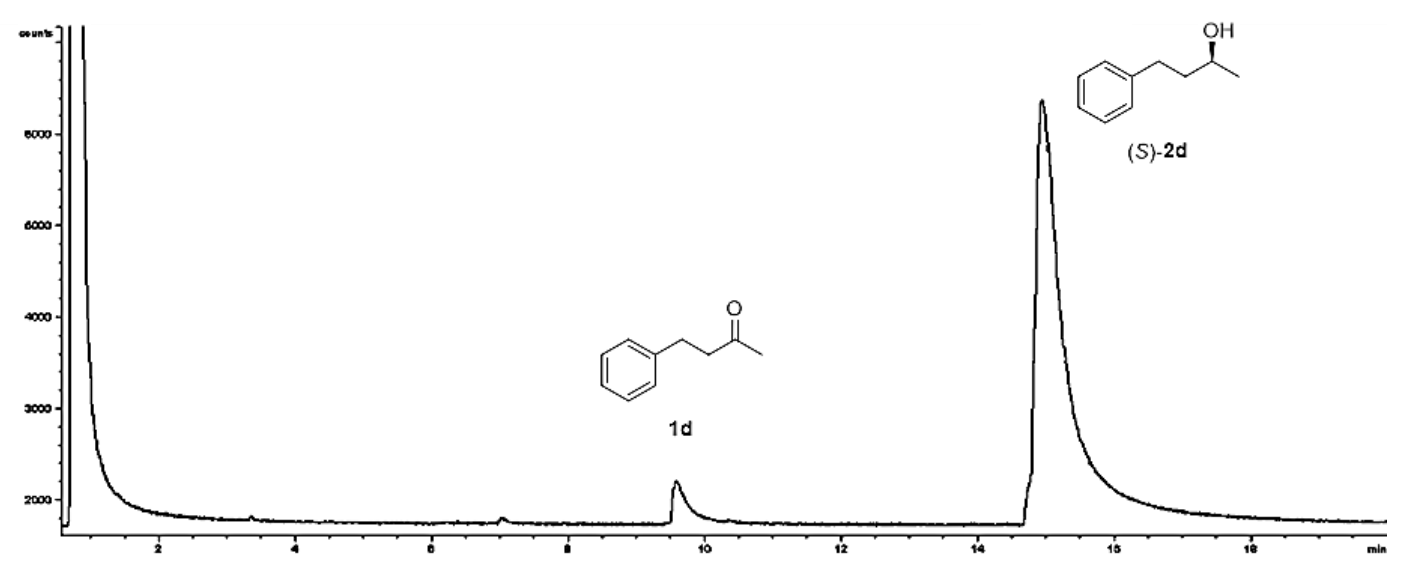

Figure S26. GC analysis of the continuous-flow bioreduction of $\mathbf{1 d}$ with immobilized yeast cell biocatalyst 


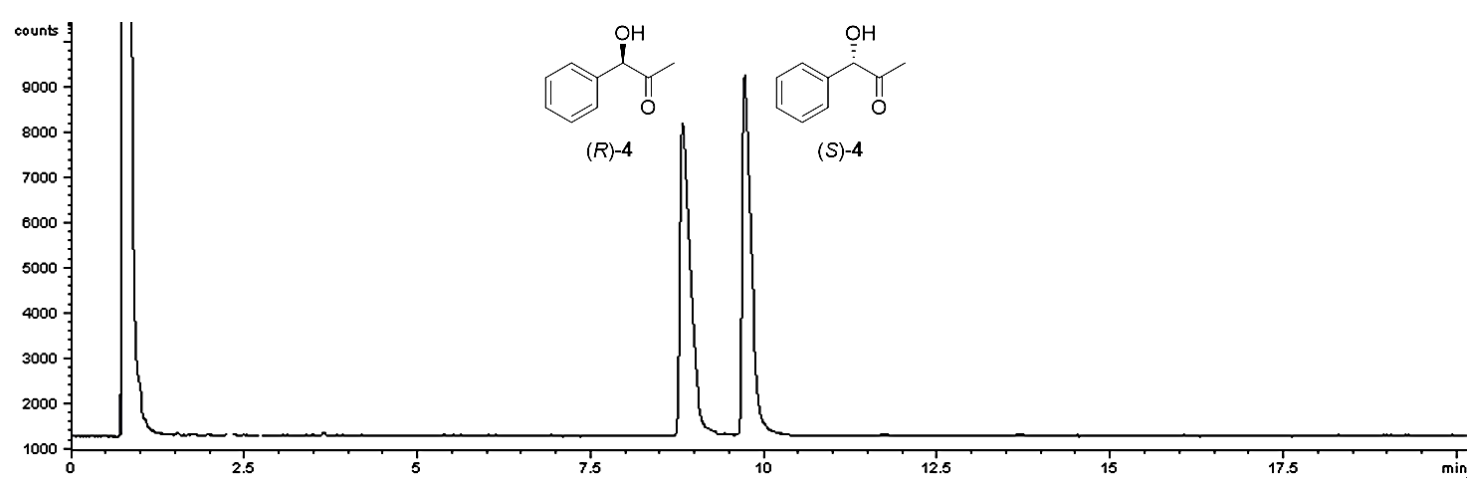

Figure S27. Reference GC chromatogram of $( \pm)-4$

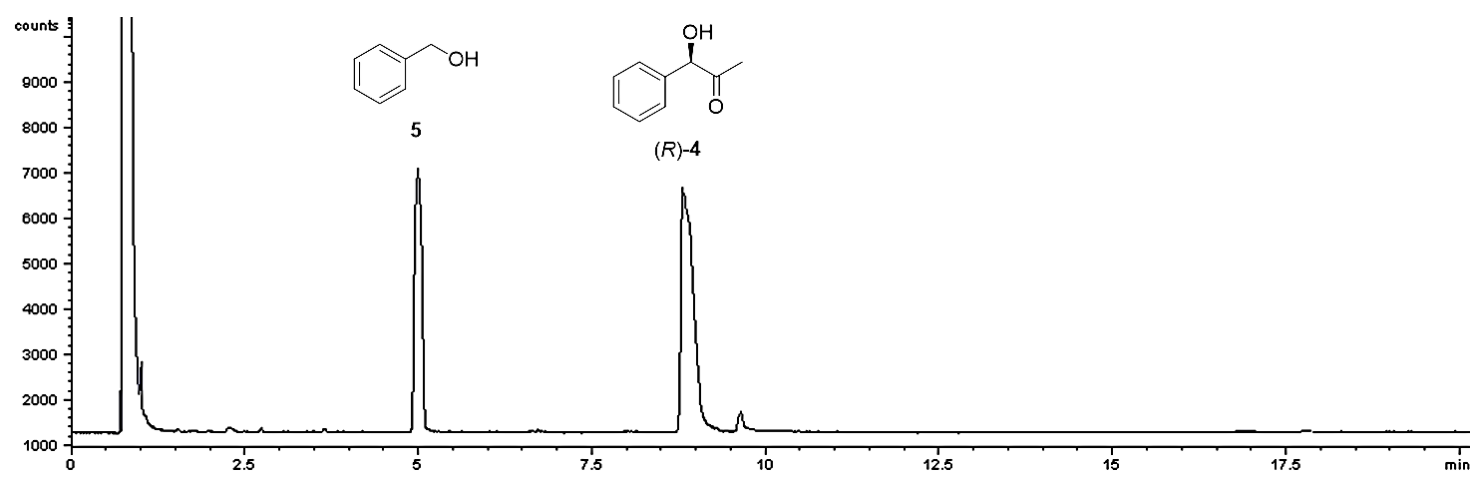

Figure S28. GC analysis of the continuous-flow acyloin condensation of benzaldehyde $\mathbf{3}$ using immobilized yeast cells

\section{References}

(1) Erdélyi, B.; Szabó, A.; Seres, G.; Birincsik, L.; Ivanics, J.; Szatzker, G.; Poppe, L. Stereoselective production of $(S)$-1-aralkyl- and 1-arylethanols by freshly harvested and lyophilized yeast cells, Tetrahedron Asymmetry 2006, 17, 268-274.

(2) Bódai, V.; Nagy-Győr, L.; Örkényi, R.; Molnár, Z.; Kohári, S.; Erdélyi, B.; Nagymáté, Z.; Romsics, C.; Paizs, C.; Poppe, L.; Hornyánszky, G. Wickerhamomyces subpelliculosus as whole-cell biocatalyst for stereoselective bioreduction of ketones, J. Mol. Catal. B Enzym. 2016, 134A, 206-214.

(3) L. Nagy-Győr, E. Abaházi, V. Bódai, P. Sátorhelyi, B. Erdélyi, D. Balogh-Weiser, C. Paizs, G. Hornyánszky, L. Poppe, ChemBioChem 2018, 19, 1845-1848.

Nagy-Győr, L.; Abaházi, E.; Bódai, V.; Sátorhelyi, P.; Erdélyi, B.; Balogh-Weiser, D.; Paizs, C.;

Hornyánszky, G.; Poppe, L. Continuous-flow cascade reaction by co-immobilized whole-cells with $\omega$ transaminase and ketoreductase activity, ChemBioChem 2018, 19(17), 1845-1848.

(4) Csajági,C.; Szatzker, G.; Tőke, E. R.; Ürge, L.; Darvas, F.; Poppe, L. Enantiomer selective acylation of racemic alcohols by lipases in continuous-flow bioreactors, Tetrahedron:Asymmetry, 2008, 19, 237-246.

(5) Iimura, S.; Manabe, K.; Kobayashi, S. Hydrophobic Polymer-Supported Catalyst for Organic Reactions in Water: Acid-Catalyzed Hydrolysis of Thioesters and Transprotection of Thiols J. Org. Chem. 2003, 68, $8723-8725$.

(6) Andreu, C.; Del Olmo, M. L. Potential of some yeast strains in the stereoselective synthesis of $(R)-(-)$ phenylacetylcarbinol and $(S)-(+)$-phenylacetylcarbinol and their reduced 1,2-dialcohol derivatives Appl. Microbiol. Biotechnol. 2014, 98, 5901-5913. 